\title{
De nominalistische theorie van de rechtssubjecten $^{*}$
}

\author{
Robert Jan Witpaard
}

Maar welk een sprekend verschijnsel de moderne staat ook zij, eensgezindheid nopens zijn bepaling bestaat niet.

Johann Logemann $(1947)^{1}$

\section{Inleiding}

In het begin van de jaren ' 40 van de vorige eeuw liet Paul Scholten zijn verhandeling over de rechtspersoon voorafgaan door de observatie dat 'geen vraag van privaatrecht (...) in de negentiende en in de eerste decennia der twintigste eeuw zozeer tot theoretische beschouwingen aanleiding [heeft] gegeven als die naar de aard van de rechtspersoon. Theorie na theorie werd verkondigd en in den brede uiteengezet.' ${ }^{2}$ Men zou aan deze opmerking nog kunnen toevoegen dat deze kwestie net zozeer speelde in het publiekrecht van die tijd. Van Hegel tot Kelsen heeft immers geen vraag van publiekrecht zozeer tot theoretische beschouwingen aanleiding gegeven als die naar de aard van de staat. Ook daar werd theorie na theorie verkondigd en in den brede uiteengezet. In zowel het privaatrecht als het publiekrecht ging het bij al deze theoretische beschouwingen in eerste instantie om een Professorenstreit in het Duitstalige rechtsgebied, gevolgd door een fikse nawee in de omringende landen, waaronder het onze. ${ }^{3} \mathrm{Na}$ de Tweede Wereldoorlog lijkt de discussie over de aard van de rechtspersoon echter vrijwel volledig te zijn stilgevallen. Dit is om ten minste drie redenen opmerkelijk.

Ten eerste is het aantal rechtspersonen nu juist in de naoorlogse periode exponentieel toegenomen, zowel in de nationale als in de internationale rechtsorde. Door met name het proces van dekolonisatie is het aantal staten in de wereld bijna verviervoudigd, terwijl er tegelijkertijd talloze nieuwe internationale organisaties zijn opgericht. De ongekende toename van het aantal commerciële rechts-

* De auteur zou graag Roel Schutgens, Joseph Fleuren, Johan Olsthoorn en de twee anonieme reviewers van de NJLP willen bedanken voor hun waardevolle commentaar op een eerdere versie van dit artikel.

1 Johann Logemann, Over de theorie van een stellig staatsrecht (Leiden: Universitaire Pers Leiden, 1947), 66.

2 Paul Scholten, 'Theoretische beschouwing,' in Mr. C. Asser's Handleiding tot de beoefening van het Nederlands Burgerlijk Recht. 2. Rechtspersonenrecht. Deel I. De Rechtspersoon, bewerkt door Maarten Kroeze (m.m.v. Hans Beckman en Maarten Verbrugh) (Deventer: Kluwer, [1940] 2015), 5.

3 Zie voor een overzicht van het negentiende-eeuwse debat: Felix Schikorski, Die Auseinandersetzung um den Körperschaftsbegriff in der Rechtslehre des 19. Jahrhunderts (Schriften zur Rechtsgeschichte, Heft 17) (Berlijn: Duncker \& Humblot, 1978). 
personen in de nationale rechtsorde is zo mogelijk nog indrukwekkender. Van 1900 tot 1964 vertienvoudigde het aantal nv's in Nederland van ongeveer 3200 naar bijna 33.000. ${ }^{4}$ Sinds de introductie van de bv in 1971 is het aantal nv's sterk teruggelopen - er zijn er op het moment nog 1155 - maar de teller van het aantal bv's staat op dit moment daarentegen op 347.915. ${ }^{5}$ Wederom meer dan een vertienvoudiging. De rechtspersoon is heden ten dage dus alomtegenwoordig. In de periode na de Tweede Wereldoorlog is daarnaast de rechtspositie van de rechtspersoon in het Nederlandse strafrecht ingrijpend veranderd. In 1976 deed de in het economische strafrecht opgegroeide rechtspersoon zijn intrede in het algemeen deel van het Wetboek van Strafrecht en sindsdien is het bepaald geen uitzondering meer dat rechtspersonen worden veroordeeld voor bijvoorbeeld levensdelicten als dood door schuld. Het leerstuk van de strafbare rechtspersoon brengt tal van lastige strafrechtelijke en dogmatische vragen met zich mee, die men pas kan beantwoorden wanneer men eerst heeft uitgelegd wat een rechtspersoon nu eigenlijk precies is. De rechtstheoretische vraag naar de 'aard' of het 'wezen' van de rechtspersoon is anno nu dan ook veel relevanter dan die ooit is geweest in de negentiende of in het begin van de twintigste eeuw. De derde en belangrijkste reden echter om zich opnieuw met de vraag naar de aard van de rechtspersoon bezig te houden, is dat dit vraagstuk tot op heden nog niet op een bevredigende wijze is opgelost. Hoewel het hier toch gaat om één van de meest fundamentele begrippen van ons juridische denken - en in het verlengde daarvan eveneens van ons gehele politieke, sociale en morele denken - is er tot op heden nog geen consensus bereikt over de vraag wat een rechtspersoon nu precies is.

In de hoop de discussie over dit vraagstuk opnieuw aan te zwengelen, zal ik in deze bijdrage niet alleen de vermetele stelling verdedigen dat geen van de tot nu gepresenteerde theorieën van de rechtspersoon de toets der kritiek kan doorstaan, maar zal ik ook een nieuwe 'nominalistische' theorie van de rechtssubjecten presenteren. Ik heb die nominalistische theorie in eerste instantie ontwikkeld om het leerstuk van de strafbare rechtspersoon van een rechtstheoretische basis te voorzien, maar ik vermoed dat zij ook interessant kan zijn voor juristen die zich bezighouden met andere vraagstukken die raken aan het thema van de rechtssubjecten. Hoewel ik uiteindelijk ook de door Hans Kelsen ontwikkelde leer van de rechtssubjecten niet kon onderschrijven, is mijn eigen visie op deze materie wel op tal van punten schatplichtig aan zijn algemene rechtsleer. Ik beschouw de door mij ontwikkelde nominalistische leer dan ook graag als een bescheiden bijdrage aan de ontwikkeling van een 'Zuivere Rechtsleer' (Reine Rechtslehre) - een project dat Kelsen graag presenteerde als een collectief wetenschappelijk project en als work in progress.

De bijdrage valt uiteen in twee delen: een constructief en een kritisch deel. Ik begin met het constructieve deel waarin ik de nominalistische theorie van de rechtssubjecten uiteen zal zetten, omdat ik in dat verband ook graag enkele

4 Cijfers van het CBS, aangehaald in: Kamerstukken II 1975/76, 13655, 9.

5 Cijfers van het CBS van 11 juli 2017, 'Bedrijven; bedrijfsgrootte en rechtsvorm' (online op http:// statline.cbs.nl/StatWeb/publication/?VW=T\&DM=SLNL\&PA=81588NED\&LA=NL). 
nieuwe begrippen en onderscheidingen zou willen introduceren die ik in het tweede deel nodig heb voor mijn kritiek op de tot nu toe gepresenteerde theorieën. In dit constructieve deel behandel ik eerst de nominalistische theorie in het algemeen (par. 1) en richt ik mij vervolgens respectievelijk op de natuurlijke persoon (par. 2) en op de rechtspersoon en diens organen (par. 3). In het tweede en meer kritisch getoonzette deel presenteer ik vervolgens een overzicht van de alternatieve theorieën van de rechtspersoon (par. 4) en probeer ik aan te tonen dat geen van deze theorieën de toets der kritiek kan doorstaan (par. 5).

\section{Deel I De nominalistische theorie van de rechtssubjecten}

\section{Het probleem van de rechtssubjecten in het algemeen}

De analyse van het probleem van de rechtssubjecten moet om twee redenen beginnen met een analyse van het rechtssysteem en niet met een analyse van de empirische werkelijkheid. Ten eerste veronderstelt het bestaan van rechtssubjecten het bestaan van een rechtssysteem: zonder rechtssysteem kunnen er ook geen rechtssubjecten bestaan. Zo is het bijvoorbeeld ondenkbaar dat individuele mensen subjecten van het volkenrecht zouden zijn, wanneer dat volkenrecht in het geheel niet zou bestaan. Ten tweede kan men de vraag welke rechtssubjecten er bestaan, uitsluitend beantwoorden aan de hand van de inhoud van een bepaald rechtssysteem. Zo kan men de vraag of het Chinese recht ook Flex bv's en onderlinge waarborgmaatschappijen kent, uitsluitend beantwoorden op basis van een juridische studie van het Chinese recht en niet op basis van een sociologische studie van de Chinese samenleving. Om vast te kunnen stellen dat er rechtssubjecten zijn en welke dat zijn, zullen we ons dus allereerst moeten richten op de inhoud van een bepaald rechtssysteem. Pas in tweede instantie kunnen we ons daarna nog wenden tot de fenomenen in de empirische werkelijkheid - en dan nog alleen door deze fenomenen te interpreteren door de bril van het desbetreffende rechtssysteem. De eerste vraag die we daarom moeten beantwoorden is: hoe manifesteren rechtssubjecten zich binnen het rechtssysteem?

Met Kelsen begrijp ik het rechtssysteem als een hiërarchisch geordend systeem van rechtsnormen. ${ }^{6}$ Het rechtssysteem is een systeem van normen en normen kunnen worden ontleed in termen van niet meer dan vijf 'elementen', namelijk: persoonlijke, normatieve, materiële, ruimtelijke en temporele elementen. Het persoonlijke element van een norm geeft aan wie of wat iets mag of moet doen: 'Jan', 'Piet', de 'stichting Wakker Dier', de 'Gemeente Stichtse Vecht', enzovoort. Het normatieve element geeft vervolgens aan of er sprake is van een gebod, een verbod, een permissie of een bevoegdheid: deze of gene 'moet', 'mag', 'is bevoegd om', enzovoort. Het materiële element geeft daarna aan om welke handeling het gaat: het 'wegnemen van een goed', het 'betalen van vennootschapsbelasting', enzovoort. Iedere norm moet in ieder geval bestaan uit een persoonlijk, een normatief 
en een materieel element. Wanneer één van deze drie elementen ontbreekt, is de norm incompleet. Bijvoorbeeld:

\begin{tabular}{lll}
\hline$[\ldots]$ & {$[\mathrm{moet}]$} & {$[500$ euro betalen aan Piet $]$} \\
Jan $]$ & {$[\ldots]$} & {$[$ een boom in zijn tuin plaatsen $]$} \\
{$[$ Shell] } & {$[\mathrm{mag}]$} & {$[\ldots]$} \\
\hline
\end{tabular}

Naast deze drie essentiële elementen kan een norm ook nog bestaan uit een ruimtelijk en/of temporeel element. Met behulp van het ruimtelijke element kan men bijvoorbeeld een bevoegdheid of een verbod beperken tot een bepaald gebied. Bijvoorbeeld: [het is een ieder] [verboden] [om te fietsen] [in het park]. Met behulp van het temporele element, kan men hetzelfde doen, maar dan voor wat betreft de tijd.

De verschillende rechtssubjecten worden traditioneel onderverdeeld in twee categorieën: natuurlijke personen en rechtspersonen. Nu ligt het voor de hand dat het probleem van deze 'personen' van het recht zal moeten worden opgelost in termen van de persoonlijke elementen van het rechtssysteem. Deze persoonlijke elementen kunnen allereerst worden onderverdeeld in algemene en individuele persoonlijke elementen. Woorden zoals 'iedereen', 'ambtenaren' of 'de koper' kunnen optreden als algemene persoonlijke elementen. Rechtsnormen die zo'n algemeen persoonlijk element bevatten, richten zich tot een open groep mensen in de empirische werkelijkheid. Zij richten zich bijvoorbeeld tot alle ambtenaren of tot iedereen die iets koopt. Het is opvallend dat morele systemen vrijwel uitsluitend algemene persoonlijke elementen bevatten. De typische morele norm geldt dan ook niet alleen 'altijd' en 'overal', maar ook voor 'iedereen'. Morele normen gelden dus in principe steeds voor alle mensen, of in ieder geval voor alle 'ouders', alle 'kinderen', alle 'vrienden', alle 'vijanden', enzovoort.

In tegenstelling tot morele normen, bevatten rechtsnormen ook dikwijls individuele persoonlijke elementen. Deze individuele persoonlijke elementen zijn vrijwel altijd namen. Bij technisch hoog ontwikkelde rechtssystemen gaat het daarbij in principe om drie verschillende soorten namen, namelijk: (1) namen die naar één mens verwijzen, (2) namen die men 'ambten' of 'organen' noemt en (3) namen die men 'rechtspersonen' of 'openbare lichamen' noemt. Volgens de hier ontwikkelde nominalistische leer moeten deze namen (nomina) worden omschreven als rechtssubjecten. Er is immers sprake van een rechtssubject, wanneer er sprake is van een zelfstandige drager van rechten, plichten en bevoegdheden. Dit zogenaamde 'dragen' van rechten, plichten en bevoegdheden moet worden uitgelegd in termen van het persoonlijke element van de rechtsnorm. Men vergelijke daartoe de volgende voorbeelden:

1 Ahmed Aboutaleb is bevoegd om hoger beroep in te stellen.

2 De burgemeester van Rotterdam is bevoegd om hoger beroep in te stellen.

3 De Gemeente Rotterdam is bevoegd om hoger beroep in te stellen. 
Deze normen bestaan alle drie uit drie elementen, namelijk: een individueel persoonlijk element (respectievelijk: 'Ahmed Aboutaleb', 'de burgemeester van Rotterdam' en 'de Gemeente Rotterdam'), een normatief element ('is bevoegd om') en een materieel element ('hoger beroep instellen'). Het normatieve element vormt tezamen met het materiële element een bepaalde bevoegdheid. Deze bevoegdheid wordt 'gedragen' door het persoonlijke element. In de eerste norm is 'Ahmed Aboutaleb' (een natuurlijk persoon) de drager van deze bevoegdheid. In de overige twee normen zijn respectievelijk 'de burgemeester van Rotterdam' (een ambt) en 'de Gemeente Rotterdam' (een rechtspersoon) de 'dragers'. Aangezien ambten en organen net zo goed zelfstandige dragers van rechten, plichten en bevoegdheden zijn als natuurlijke personen en rechtspersonen, zijn ambten en organen ook net zo goed rechtssubjecten. De traditionele dichotomie tussen natuurlijke personen en rechtspersonen moet daarom in ieder geval nog worden aangevuld met een derde categorie die de ambten en/of organen omvat. In de volgende paragraaf richt ik me eerst op de natuurlijke persoon, daarna ga ik in op de overige rechtssubjecten.

\section{De natuurlijke persoon}

De zogenaamde 'natuurlijke persoon' wordt doorgaans simpelweg gedefinieerd als een mens van vlees en bloed, dat wil zeggen als een biologische entiteit. Het individuele persoonlijke element 'Ahmed Aboutaleb' - dat we hierboven tegenkwamen als onderdeel van een rechtsnorm - is echter geen mens, maar een naam die verwijst naar een mens. Naast de feitelijke mens, moeten we bij het rechtssubject 'natuurlijk persoon' dus eveneens diens juridische naam in de analyse betrekken. Volgens de politicoloog en antropoloog James C. Scott vindt het huidige systeem van juridisch vastgelegde voor- en achternamen haar oorsprong in de middeleeuwse belastingheffing. ${ }^{7}$ Tot de veertiende eeuw had de overgrote meerderheid van de Europese bevolking nog geen achternaam, terwijl vrijwel alle mannen uit die tijd wel zo ongeveer dezelfde christelijke voornamen hadden. De administratieve noodzaak om individuele mensen op een ondubbelzinnige manier te kunnen identificeren, heeft de middeleeuwse belastinginners er daarom toe gebracht om aan alle belastingplichtigen een achternaam toe te kennen. Het ging daarbij meestal om een toponiem (Van Breda, Van den Heuvel) een familierelatie (Janszoon, Johnson), een beroep (Bakker, Smit) of een uiterlijk kenmerk (De Korte, De Groote). ${ }^{8}$ In verband met het evidente belang voor de rechtszekerheid, worden deze voor- en achternamen sinds de napoleontische tijd met de grootst mogelijke nauwkeurigheid van staatswege geregistreerd. Het gaat bij deze voor- en achternamen dus nadrukkelijk niet om sociale conventies, maar om juridisch vastgelegde namen. Deze namen vormen een wezenlijk onderdeel van de inhoud van het rechtssysteem en zij kunnen daarom ook alleen maar via bepaalde juridische pro- 
cedures worden gewijzigd. ${ }^{9}$ In moderne verzorgingsstaten met miljoenen mensen komen sommige combinaties van voor- en achternamen echter weer zo vaak voor dat uiteindelijk ook deze namen weer onvoldoende onderscheidend vermogen hebben. De administratieve noodzaak om miljoenen mensen op een efficiënte en volstrekt ondubbelzinnige manier te kunnen identificeren, dwingt er daarom uiteindelijk toe om aan ieder individu een uniek nummer - bijvoorbeeld een burgerservicenummer ${ }^{10}$ - toe te kennen.

De introductie van individuele persoonlijke elementen - namen of nummers - die verwijzen naar één enkel mens is een cruciale stap in de technische ontwikkeling van een rechtssysteem. Door aan alle mensen een naam of een nummer toe te kennen, wordt het immers mogelijk om met behulp van contracten, beschikkingen of strafvonnissen de rechtspositie van één enkel individu te bepalen. Moderne rechtssystemen zijn daarom ook in staat om aan miljoenen mensen een volstrekt unieke rechtspositie toe te kennen. Morele systemen zijn daartoe niet in staat, omdat zij uitsluitend werken met algemene persoonlijke elementen. Morele normen gelden daarom steeds gelijkelijk voor eenieder die zich in dezelfde feitelijke situatie bevindt of voor eenieder die 'ouder', 'kind', 'vriend', 'vijand', enzovoort is. Omdat alleen rechtssystemen gebruik maken van individuele persoonlijke elementen, kunnen mensen dus wel een volstrekt unieke rechtspositie hebben, maar geen volstrekt unieke morele positie.

Dit wezenlijke verschil tussen de inhoud van morele systemen en de inhoud van rechtssystemen betekent eveneens dat er een verschil bestaat tussen de 'subjecten' van de moraal en de 'subjecten' van het recht. De subjecten van de moraal zijn vrijwel altijd 'extra-systemische' subjecten die zich buiten het morele systeem bevinden. Dat wil zeggen, bij de subjecten van de moraal gaat het vrijwel altijd om mensen van vlees en bloed, die op een bepaald moment onder de extensie van een algemene morele norm vallen. Bij de subjecten van het recht moeten we daarentegen een onderscheid maken tussen 'extra-systemische' en 'intra-systemische' subjecten. Zoals ik in de volgende paragraaf nog nader zal betogen, zijn 'rechtspersonen' (of 'openbare lichamen') en 'ambten' (of 'organen') louter intra-systemische subjecten: deze rechtssubjecten zijn niets meer dan namen binnen het rechtssysteem. Dat er wel 'rechtspersonen' en 'juridische ambten' bestaan, maar geen 'moraalpersonen' of 'morele ambten' heeft dan ook niets te maken met de specifieke stand van zaken in de empirische werkelijkheid - die is immers steeds voor beide type systemen precies hetzelfde -, maar uitsluitend met de specifieke inhoud van deze normatieve systemen. ${ }^{11}$

9 De wijziging van een voornaam kan op verzoek van de betrokken persoon of zijn wettelijke vertegenwoordiger worden gelast door de rechtbank (art. 1:4 lid 4 BW). De geslachtsnaam kan slechts bij koninklijk besluit worden gewijzigd (art. 1:7 lid 1 BW).

10 Zie daarvoor de Wet algemene bepalingen burgerservicenummer, Stb. 2007/288.

11 In de normatieve systemen van de politieke filosofie - bijvoorbeeld in de systemen van Hobbes en Locke - treft men uiteraard wel subjecten zoals de 'Sovereign' en de 'Commonwealth' aan. Opvallend is echter dat men ook in deze systemen doorgaans geen individuele persoonlijke elementen aantreft: men bespreekt slechts 'de' soeverein en niet soeverein X, Y en Z. 
Voor zover rechtssystemen gebruik maken van individuele persoonlijke elementen die verwijzen naar één enkel mens, moet er ook bij het rechtssubject 'natuurlijk persoon' een onderscheid worden gemaakt tussen de natuurlijke persoon als extra-systemisch subject en de natuurlijke persoon als intra-systemisch subject. Als feitelijk mens is de natuurlijke persoon een extra-systemisch subject, dat zich buiten het rechtssysteem bevindt en daaraan 'onderworpen' (subjectum) is. Als juridische naam is de natuurlijke persoon daarentegen een intra-systemisch subject, dat zich binnen het rechtssysteem bevindt en daarvan een onderdeel is. Bij de intra-systemische subjecten van het recht spreekt men op een taalkundige wijze over het 'subject' van een norm, zoals men in de logica spreekt over het 'subject' van een propositie. Men vergelijke daartoe de volgende twee voorbeelden:

propositie:

norm:
Jan betaalt 500 euro aan Piet.

Jan moet 500 euro betalen aan Piet.

Het subject van de propositie is de eigennaam 'Jan' en deze eigennaam is een onderdeel van de propositie. Buiten de propositie - in de empirische werkelijkheid - bevindt zich eventueel ook nog een Jan van vlees en bloed, over wie in deze propositie iets wordt gezegd. Op een vergelijkbare manier kunnen we zeggen dat de eigennaam 'Jan' het subject is van de hierboven gepresenteerde norm. Het subject van de norm - en daarmee van het recht - is in dit geval dus niet iets buiten de norm, maar een onmisbaar onderdeel van de norm. Het is het persoonlijke element van de norm. ${ }^{12}$

Een individueel persoonlijk element - een naam of een nummer - fungeert binnen het rechtssysteem als een 'punt' waaraan (1) een rechtspositie kan worden toegekend en waaraan (2) menselijk gedrag kan worden toegeschreven of toegerekend. Zoals we hierboven al hebben gezien, fungeren juridisch vastgelegde namen allereerst als 'dragers' van rechten, plichten en bevoegdheden. Huizen, auto's en bankrekeningen staan dan ook letterlijk 'op naam van' deze of gene. In de alledaagse rechtspraktijk is de naam van een natuurlijk persoon ook een stuk belangrijker dan zijn biologische lichaam: wie bijvoorbeeld via het internet een boek wil kopen of in een restaurant een tafel wil reserveren, stuurt geen foto door van zijn lichaam, maar noemt zijn naam. Het lichaam van een natuurlijk persoon speelt uiteraard wel een zekere rol bij de creatie en de toepassing van het recht, maar de

12 In navolging van Kelsen gebruik ik de term 'norm' als de overkoepelende term voor verdragen, wetten, contracten, vonnissen, enz. Een 'algemene norm' is een norm met een algemeen persoonlijk element, een 'individuele norm' is een norm met een individueel persoonlijk element, bijv. een beschikking. Bij dit onderscheid moet worden aangetekend dat men slechts in een taalkundige - en niet in een rechtstheoretische - zin van algemene normen kan spreken. In de norm 'soldaten moeten de bevelen van hun superieuren opvolgen' fungeert het woord 'soldaten' als het persoonlijke element van de norm. Dit persoonlijke element is een algemeen persoonlijk element en men zou deze norm daarom kunnen beschrijven als een algemene norm. Deze algemene norm normeert echter het gedrag van individuele rechtssubjecten, aangezien er uitsluitend individuele en geen algemene rechtssubjecten bestaan. Wat men taalkundig beschrijft als een algemene norm, moet rechtstheoretisch gezien daarom worden begrepen als een $\mathrm{X}$ aantal individuele normen, of zo men wil, als een $\mathrm{X}$ aantal subjectieve rechten of plichten. 
inhoud van het recht kan uitsluitend zijn of haar naam bevatten. Lichamen van vlees en bloed laten zich immers niet in een rechtssysteem opnemen.

Net als de namen die we rechtspersonen of organen noemen, fungeren de namen van natuurlijke personen daarnaast ook nog als toerekeningspunten van menselijk gedrag. In het strafproces moet de rechter bijvoorbeeld de 'identiteit' van de verdachte vaststellen (art. $273 \mathrm{~Sv}$ ). Dat wil zeggen, de rechter moet uitzoeken welke juridische naam verwijst naar dit mens van vlees en bloed. De vaststelling dat dit mens juridisch gezien 'Jan de Boer' of 'Piet de Vries' is, is net zozeer een interpretatie en kwalificatie van de empirische werkelijkheid op basis van het rechtssysteem, als de vaststelling dat zijn handeling juridisch gezien 'moord' of 'doodslag' is. Wanneer de rechter ervan overtuigd is dat dit mens juridisch gezien 'Jan de Boer' is en dat zijn handeling juridisch gezien 'moord' is, dan zal hij in zijn vonnis moeten opschrijven dat 'Jan de Boer' (een naam) het strafbare feit 'moord' heeft begaan. De handeling van een mens in de empirische werkelijkheid is dan gezaghebbend toegerekend aan een naam binnen het rechtssysteem.

Het is zeer wel mogelijk dat ook de gedragingen van andere mensen dan Jan de Boer aan de naam 'Jan de Boer' worden toegeschreven. In het burgerlijk recht kunnen we bijvoorbeeld denken aan vertegenwoordigingsrelaties, in het strafrecht zou het kunnen gaan om een verdachte die tegenover een politieagent een valse naam opgeeft. Wanneer Piet de Vries een verkeersovertreding begaat en hij vervolgens de agent ervan weet te overtuigen dat zijn naam 'Jan de Boer' is, dan zal de agent de door hem geconstateerde handeling toerekenen aan de naam 'Jan de Boer' en niet aan de naam 'Piet de Vries'. De naam 'Jan de Boer' fungeert in dat geval dus als het toerekeningspunt van het gedrag van Piet de Vries, zodat de boete uiteindelijk niet bij Piet, maar bij de niets vermoedende Jan op de mat zal vallen.

Normaliter verwijzen de juridisch vastgelegde namen van natuurlijke personen naar daadwerkelijk bestaande mensen, maar dit hoeft niet noodzakelijkerwijze het geval te zijn. Het is immers zeer wel mogelijk dat een naam binnen het rechtssysteem niet, nog niet of niet meer naar een mens in de empirische werkelijkheid verwijst. Wanneer men bijvoorbeeld aan een nog ongeboren kind publiekrechtelijke bevoegdheden of een erfenis wil toekennen, dan kan men al voor diens geboorte een individueel persoonlijk element - een combinatie van voor- en achternamen - aan het rechtssysteem toevoegen. De heersende leer, die de natuurlijke persoon uitsluitend begrijpt als een mens van vlees en bloed, heeft zich genoodzaakt gezien om deze mogelijkheid te construeren met behulp van de fictie dat het ongeboren kind reeds geboren is. ${ }^{13}$ Volgens de nominalistische leer is een dergelijke fictie echter in wezen overbodig, aangezien we hier in feite te maken hebben met twee volstrekt verschillende en van elkaar onafhankelijke gebeurtenissen. Aan de ene kant hebben we te maken met een biologische gebeurtenis - de geboorte van een kind die nog even op zich laat wachten - en aan de andere kant hebben we te maken met een juridische gebeurtenis - de introductie van een indi- 
vidueel persoonlijk element in het rechtssysteem, dat kan fungeren als de drager van rechten, plichten en bevoegdheden. Tussen deze twee gebeurtenissen bestaat geen enkel noodzakelijk verband, zodat het in beginsel volledig aan de wetgever is om te bepalen of en wanneer een (potentieel) mens als rechtssubject wordt erkend. De juridische creatie van het rechtssubject 'natuurlijk persoon' hoeft men dan ook geenszins afhankelijk te maken van een (louter fictieve) biologische gebeurtenis.

Dat we bij het rechtssubject 'natuurlijk persoon' een onderscheid moeten maken tussen een extra-systemisch en een intra-systemisch subject blijkt ook uit tal van andere voorbeelden. Zo zou men bijvoorbeeld kunnen frauderen met de kinderbijslag door aangifte te doen van de geboorte van een kind dat in feite nooit geboren is. Op een vergelijkbare manier kan men de namen van de doden nog even op de kieslijst laten staan, om ze vervolgens allemaal per volmacht op een bepaalde kandidaat te laten stemmen. Bij de turbulente Tweede Kamerverkiezingen van 2002 - die negen dagen na de moord op Pim Fortuyn plaatsvonden - bleek dat de doden zelfs nog een passief kiesrecht kan toekomen. Hoewel er in al dit soort gevallen geen daadwerkelijke mensen (meer) in de empirische werkelijkheid bestaan, bestaan er binnen het rechtssysteem - al dan niet terecht - (nog) wel degelijk allerlei namen die optreden als 'dragers' van rechten, plichten en bevoegdheden.

Net zoals bij de rechtspersonen, treft men ten slotte ook bij de natuurlijke personen niet alleen een heleboel species aan, maar ook verschillende genera. Zo kende het Romeinse recht de genera Romeins burger, niet-Romein en slaaf, terwijl het Zuid-Afrikaanse recht gedurende de apartheid een onderscheid maakte tussen black, white, coloured en Indian. In het huidige Nederlandse rechtssysteem wordt er onder meer een onderscheid gemaakt tussen Nederlanders, Unieburgers en derdelanders. De algemene of initiële rechtspositie van individuele mensen kan dus aanzienlijk verschillen, afhankelijk van het genus 'natuurlijk persoon' waartoe zij behoren. De rechtspositie van een individueel mens kan daarom uiteindelijk ook op drie verschillende manieren worden veranderd, namelijk: (1) door de algemene rechtspositie van het genus 'natuurlijk persoon' waartoe hij of zij behoort te veranderen, (2) door de individuele rechtspositie die specifiek met zijn of haar juridische naam verbonden is te veranderen of (3) door hem of haar als mens onder de extensie van een algemene norm te brengen.

Het rechtssubject 'natuurlijk persoon' kan volgens de nominalistische leer dus niet simpelweg worden gedefinieerd als een mens van vlees en bloed, dat wil zeggen als een biologische entiteit. In plaats daarvan moet er een onderscheid worden gemaakt tussen de natuurlijke persoon als extra-systemisch rechtssubject (een mens) en de natuurlijke persoon als intra-systemisch rechtssubject (een naam). Een mens van vlees en bloed kan daarbij pas worden omschreven als een extra-systemisch rechtssubject, wanneer het rechtssysteem ten minste één van zijn of haar handelingen normeert. Met Kelsen kan daaraan nog worden toegevoegd dat geen enkel rechtssysteem alle mentale en fysieke functies van de mens normeert, zodat een mens ook nooit in de totaliteit van zijn of haar fysieke exis- 
tentie aan het recht onderworpen kan zijn. ${ }^{14}$ Welbeschouwd gaat het bij de natuurlijke persoon als extra-systemisch rechtssubject dus niet om de mens als geheel, maar uitsluitend om de mens als handelend subject. Het recht normeert immers niet de mens als zodanig, maar uitsluitend zijn of haar gedrag. De mens als geheel - de mens als eenheid van lichaam en geest - kan daarom uitsluitend op het juridische toneel verschijnen als een rechtsobject waar het handelen van de rechtssubjecten op in kan werken. Zo kan het menselijke lichaam bijvoorbeeld worden onderworpen aan straffen, dwangmiddelen of medische ingrepen.

De verschillende betekenissen van de term 'natuurlijk persoon' - de natuurlijke persoon als intra-systemisch rechtssubject, als extra-systemisch rechtssubject en als rechtsobject - moeten nauwkeurig van elkaar worden onderscheiden en er moet om die reden bezwaar worden aangetekend tegen het door Britta van Beers verdedigde 'hybride' persoonsbegrip, waarin deze betekenissen met elkaar worden vermengd. In navolging van de Franse rechtshistorici Thomas, Baud en Deroussin maakt Van Beers bij haar analyse van de natuurlijke persoon een onderscheid tussen een artificialistische traditie die teruggaat op het Romeinse recht en een naturalistische traditie die teruggaat op het canonieke recht. ${ }^{15}$ Bij de Romeinen ging het in eerste instantie om de juridische 'rol' of het 'masker' (persona) die een bepaald mens (homo) door het recht kreeg toebedeeld. ${ }^{16}$ Een enkel mens kon in deze artificialistische traditie meerdere personae tegelijkertijd zijn, bijvoorbeeld pater familias, debiteur, eigenaar, verkoper, enzovoort. ${ }^{17}$ In een later stadium ging het in deze traditie hoofdzakelijk om de door het recht aan het individu geattribueerde capaciteit om verschillende juridische rollen te spelen. ${ }^{18}$ In de naturalistische traditie van het middeleeuwse canonieke recht richtte men zich daarentegen op de persoon als eenheid van lichaam en ziel. ${ }^{19}$

Het onderscheid tussen deze twee tradities blijkt bij nader inzien niet geheel waterdicht te zijn. Aan de ene kant veronderstelt de artificialistische traditie van de Romeinen namelijk een naturalistisch begrip van het rechtssubject 'natuurlijk persoon'. De verschillende juridische 'maskers' (personae) worden uiteindelijk immers gedragen door biologische mensen (homines). Aan de andere kant blijkt het in de naturalistische traditie niet zozeer om de biologische mens te gaan, maar veeleer om een religieus mensbeeld dat in latere eeuwen zou worden geseculariseerd. ${ }^{20}$ Wanneer uiteindelijk ook dit naturalistische persoonsbegrip door Van Beers wordt gepresenteerd als een 'artefact' en een 'juridische constructie', komt

Hans Kelsen, General Theory of Law and State, vert. Anders Wedberg (van een niet gepubliceerd manuscript) (Cambridge, MA: Harvard University Press, 1945); herduk met een nieuw voorwoord door A. Javier Treviňo (New Brunswick, NJ: Transaction Publishers, 2007), 94. [Hierna: GTLS 1945]

15 Britta van Beers, Persoon en lichaam in het recht. Menselijke waardigheid en zelfbeschikking in het tijdperk van de medische biotechnologie (Den Haag: Boom juridische uitgevers 2009), 52.

16 Van Beers, Persoon en lichaam in het recht, 53.

17 Van Beers, Persoon en lichaam in het recht, 54.

18 Van Beers, Persoon en lichaam in het recht, 56.

19 Van Beers, Persoon en lichaam in het recht, 67.

20 Van Beers, Persoon en lichaam in het recht, 72. 
het onderscheid tussen deze twee tradities in feite te vervallen. ${ }^{21}$ Problematischer dan dit onderscheid is echter het feit dat al deze persoonsbegrippen worden vermengd tot één enkel persoonsbegrip. Van Beers stelt namelijk dat de Franse rechtshistorici overtuigend hebben aangetoond 'hoe de juridische persoon een hybride heeft kunnen worden van biologie en recht, feit en constructie, empirische werkelijkheid en juridische werkelijkheid, collectiviteit en individualiteit, natuur en samenleving' ${ }^{22}$

Een dergelijk 'hybride' persoonsbegrip is onhoudbaar. Personen die tegelijkertijd zowel recht, biologie als normatief mensbeeld zijn, bestaan immers niet. Wat Van Beers presenteert als 'het hedendaagse juridische persoonsbegrip' is in feite het resultaat van een ontoelaatbare vermenging van rechtswetenschap met biologie, religie en ethiek. Bij de theorie van de rechtssubjecten - en dus ook bij de theorie van de 'natuurlijke persoon' - kan het uitsluitend gaan om een analyse van de persoonlijke elementen van het rechtssysteem of om een interpretatie van de empirische werkelijkheid op basis van deze persoonlijke elementen. Biologie, religie en ethiek spelen hierbij geen enkele rol. In de volgende paragraaf zullen we zien dat een zorgvuldige analyse van de persoonlijke elementen van het rechtssysteem van nog groter belang is voor een goed begrip van de rechtspersoon en diens organen.

\section{Rechtspersonen en organen}

In de vorige paragraaf heb ik de introductie van individuele persoonlijke elementen die verwijzen naar één enkel mens beschreven als een belangrijke technische ontwikkeling van het rechtssysteem. Door de introductie van deze individuele persoonlijke elementen kan men het rechtssysteem laten differentiëren tussen verschillende individuen, zodat men uiteindelijk aan miljoenen individuen een volstrekt unieke rechtspositie kan toekennen. Morele systemen zijn daartoe niet in staat, omdat zij uitsluitend werken met algemene persoonlijke elementen. In tegenstelling tot rechtssystemen, kennen morele systemen geen namen toe aan individuele mensen en er bestaat dan ook niet zoiets als een moreel equivalent van de burgerlijke stand. Een volgende stap in de technische ontwikkeling van het rechtssysteem is de introductie van individuele persoonlijke elementen die men 'ambten' of 'organen' noemt.

Bij de ambten en organen gaat het om persoonlijke elementen binnen het rechtssysteem en niet om bepaalde mensen buiten het rechtssysteem. Door het rechtssysteem te gebruiken als interpretatieschema van de empirische werkelijkheid, kunnen we bepaalde mensen wel interpreteren als 'burgemeester van Rotterdam' of als 'Nationale ombudsman'. Zonder rechtssysteem is een dergelijke interpretatie echter niet mogelijk, zodat er zonder rechtssysteem ook geen burgemeesters of Nationale ombudsmannen kunnen zijn. In tegenstelling tot de namen die verwijzen naar één enkel mens, verwijzen de woorden 'burgemeester van Rotterdam' en 'Nationale Ombudsman' echter niet direct en permanent naar één bepaald individu in de werkelijkheid. Door middel van overerving, benoeming of verkie- 
zing zal er daarom eerst nog moeten worden bepaald wie er precies 'burgemeester van Rotterdam' of 'Nationale ombudsman' zal zijn. De individuele persoonlijke elementen 'burgemeester van Rotterdam' en 'Nationale ombudsman' verwijzen om die reden dan ook slechts indirect en tijdelijk naar bepaalde mensen in de empirische werkelijkheid. Bij de ambten en organen bestaat er daarom ook een andersoortige relatie tussen het individu in de empirische werkelijkheid en het individuele persoonlijke element binnen het rechtssysteem. ${ }^{23}$ Ook dit tweede type van individuele persoonlijke elementen komen we niet tegen in morele systemen en er bestaan om die reden dan ook geen morele 'ambten' of 'organen'.

De derde en laatste stap in de technische ontwikkeling van het rechtssysteem is de introductie van individuele persoonlijke elementen die men 'rechtspersonen' noemt. Rechtspersonen zijn vrijwel altijd een individueel exemplaar van een bepaald type rechtspersoon en de creatie van rechtspersonen vereist daarom over het algemeen een aantal voorbereidende stappen. Zo zal de wetgever allereerst een bepaald type of genus rechtspersoon moeten introduceren, bijvoorbeeld 'gemeente', 'stichting' of 'naamloze vennootschap'. Vervolgens zal de wetgever moeten bepalen welke rechten, plichten en bevoegdheden de individuele exemplaren van zo'n type zullen krijgen, dat wil zeggen de wetgever moet de initiële of algemene rechtspositie van die rechtspersonen vaststellen. Typisch voor de rechtspersoon is dat deze daarbij wordt gebonden aan een bepaald economisch, cultureel of charitatief doel. Net als de namen die men 'ambten' of 'organen' noemt, verwijzen de namen die men 'rechtspersoon' noemt niet direct naar bepaalde individuen in de empirische werkelijkheid. Anders dan bij de ambten en de organen het geval is, worden er echter ook geen individuen gekozen of benoemd als 'gemeente', 'stichting' of 'nv'. De namen die we rechtspersonen noemen, staan daarom in eerste instantie niet 'in contact' met mensen van vlees en bloed buiten het rechtssysteem. Om de rechtspersoon toch in staat te stellen om op het juridische 'moeten' te reageren, moet de rechtspersoon daarom altijd worden voorzien van één of meer ambten of organen. Ten slotte zal de wetgever nog moeten aangeven hoe een individueel exemplaar van een bepaald type rechtspersoon kan worden gecreëerd, bijvoorbeeld bij wet of bij notariële akte. Alleen de individuele exemplaren - de species - zijn rechtssubjecten en al deze individuele exemplaren moeten uiteraard ook weer een eigen naam krijgen: 'Gemeente Rot-

23 Bij de individuele ambten doet zich daarnaast nog een merkwaardig verschijnsel in ons spraakgebruik voor. Wanneer Aad Bert vertegenwoordigt, dan zeggen we niet dat Aad Bert 'is', maar dat Aad handelt 'in naam van' of als 'vertegenwoordiger' van Bert. Hetzelfde geldt voor collegiale ambten en rechtspersonen. Ook daar zeggen we niet dat iemand de gemeente of de gemeenteraad 'is', maar dat hij handelt 'in naam van' die rechtspersoon of als 'vertegenwoordiger' van dat orgaan. Bij de individuele ambten zeggen we echter wel dat iemand de burgemeester of de ombudsman 'is', terwijl het in feite een stuk consequenter zou zijn om ook in deze gevallen te zeggen dat iemand optreedt 'in naam van' of als 'vertegenwoordiger' van dat ambt. 
terdam', 'Stichting Wakker Dier', 'Koninklijke Philips N.V.', enzovoort. ${ }^{24}$ Er bestaat geen wezenlijk verschil tussen het 'wezen' van de privaatrechtelijke rechtspersoon en het 'wezen' van de publiekrechtelijke rechtspersoon. Het enige verschil is dat de privaatrechtelijke rechtspersoon wordt gecreëerd krachtens het privaatrecht en dat de publiekrechtelijke rechtspersoon wordt gecreëerd krachtens het publiekrecht.

Volgens de hier gepresenteerde nominalistische leer van de rechtspersoon, zijn rechtspersonen dus in eerste instantie niets meer dan namen (nomina) binnen het rechtssysteem. Rechtspersonen zijn echter wel weer meer dan alleen maar namen, omdat zij binnen het rechtssysteem fungeren als 'punten', waaraan een bepaalde rechtspositie kan worden toegekend en waaraan menselijk gedrag kan worden toegeschreven of toegerekend. Binnen het rechtssysteem fungeren deze namen dus als dragers van rechten, plichten en bevoegdheden en als toerekeningspunten van menselijk gedrag. Ook dit derde type van individuele persoonlijke elementen komen we niet tegen in morele systemen en er bestaan om die reden dan ook geen 'moraalpersonen'.

Omdat rechtspersonen, anders dan natuurlijke personen, zuiver intra-systemische rechtssubjecten zijn - die uitsluitend binnen het rechtssysteem bestaan bestaat er tussen rechtspersonen en natuurlijke personen een zeer wezenlijk verschil in de wijze waarop zij 'normadressaten' zijn. Een voorbeeld kan dit verschil verduidelijken. De norm 'rechtspersonen van type $N$ moeten vennootschapsbelasting betalen' is gericht tot rechtspersonen. Rechtspersonen zijn in dit geval de directe normadressaten. Deze directe normadressaten zijn echter zelf niet in staat om gehoor te geven aan de tot hen gerichte norm. Rechtspersonen hebben immers geen handen en geen voeten en zij zijn daarom ook niet in staat om zelf de relevante handelingen te verrichten. De relevante handelingen kunnen uitsluitend worden verricht door mensen van vlees en bloed die handelen in naam van de rechtspersoon. Wil een norm die zich direct tot een rechtspersoon richt niet

24 Het materiaal dat men nodig heeft voor de constructie van rechtspersonen - (1) een genusbegrip, (2) namen voor de individuele species en (3) namen die verwijzen naar mensen in de empirische werkelijkheid die kunnen optreden als vertegenwoordigers - zou men uiteraard ook kunnen gebruiken om nieuwe categorieën rechtssubjecten te creëren, bijvoorbeeld 'dieren' of 'toekomstige generaties'. Dat men voor een dergelijke constructie meer nodig heeft dan alleen maar een genus-begrip, blijkt wellicht het duidelijkst uit de gebrekkige wijze waarop men in het moderne volkenrecht aan 'volken' een rechtspositie heeft willen toekennen. In art. 1 IVBPR wordt er bijv. een recht op zelfbeschikking toegekend aan 'alle volken': '[All peoples] [have the right of] [self-determination].' Bij het algemene persoonlijke element 'alle volken' gaat het nog slechts om het genus-begrip 'volk', terwijl uiteindelijk alleen de individuele species van dat genus rechtssubject kunnen zijn. Het verdrag laat echter na om te bepalen door wie en op basis van welke criteria er zal moeten worden vastgesteld of er in de empirische werkelijkheid sprake is van een individueel 'volk'. Deze gezaghebbende vaststelling is niettemin noodzakelijk om voor zo'n individueel volk een individueel persoonlijk element - een naam - aan het volkenrecht te kunnen toevoegen: het Koerdische volk heeft recht op zelfbeschikking, het Friese volk heeft recht op zelfbeschikking, enzovoort. Het verdrag bepaalt evenmin welke mensen in de empirische werkelijkheid als vertegenwoordigers van zo'n individueel volk zouden kunnen optreden. De regeling is juridisch-technisch gezien dus incompleet. 
volstrekt onzinnig zijn - omdat de directe normadressaat er nooit gehoor aan zal kunnen geven - dan moet die norm dus worden geacht zich indirect tot bepaalde mensen in de empirische werkelijkheid te richten. Mensen van vlees en bloed zijn in dat geval dus de indirecte normadressaten. Welke mensen in een bepaald geval te gelden hebben als de indirecte normadressaten, wordt echter niet bepaald door de norm die zich tot de rechtspersoon richt. De norm die zich tot een rechtspersoon richt, is door Kelsen daarom ook wel beschreven als een incomplete norm: de norm is ergänzungsbedürftig, omdat het persoonlijke element van die norm - het 'wie' van die norm - nog nader moet worden aangevuld. ${ }^{25}$

De nominalistische leer van de rechtspersoon levert het volgende (gesimplificeerde) beeld op van de Gemeente Rotterdam, van diens ambten en organen en van diens ambtsdragers en ambtenaren:

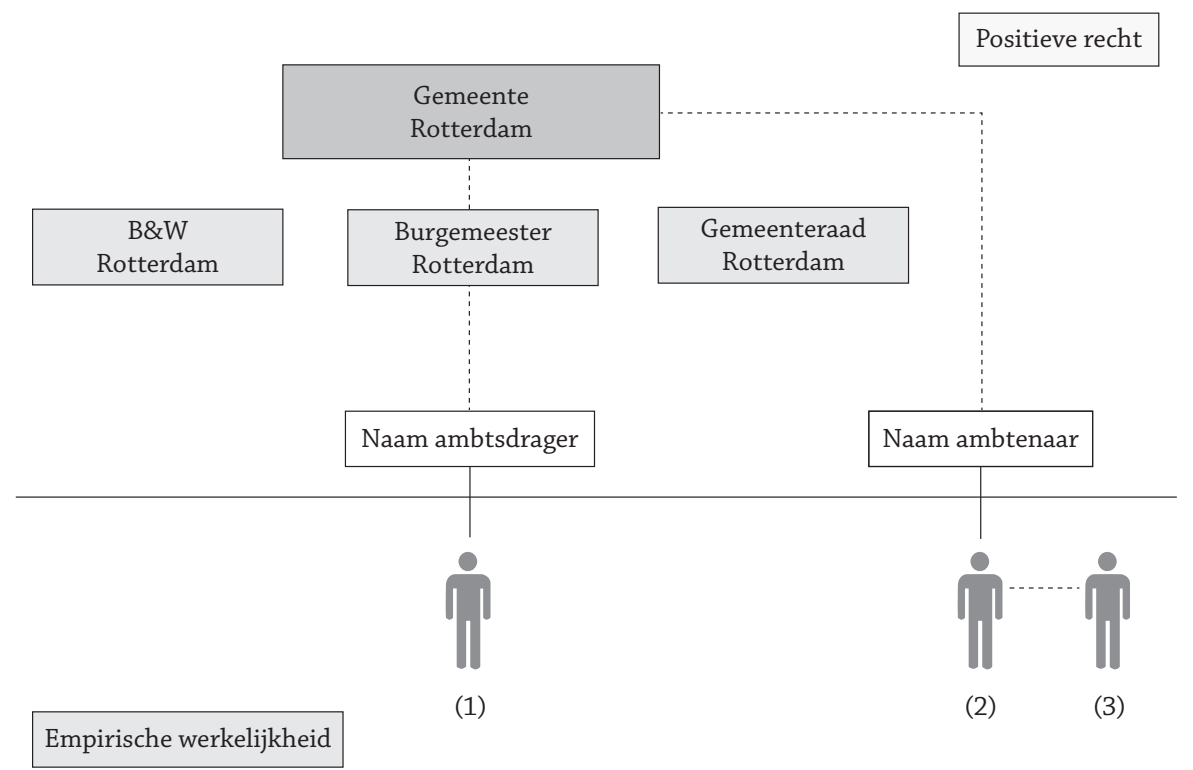

Boven de streep - in het positieve recht - treffen we allereerst een 'puntenstructuur' aan, die bestaat uit drie lagen: de naam die men 'rechtspersoon' of 'openbaar lichaam' noemt, de namen die men 'ambten' of 'organen' noemt en de namen van bepaalde natuurlijke personen. Onder de streep - in de empirische werkelijkheid - kunnen we vervolgens bepaalde mensen aanwijzen, die een juridische relatie met de rechtspersoon en/of diens ambten en organen hebben. Het gaat daarbij grofweg om (1) de ambtsdragers en (2) de ambtenaren. Tezamen vormen deze mensen van vlees en bloed de feitelijke organisatie van de rechtspersoon. De eenheid van deze groep mensen - die zich in principe overal ter wereld kunnen bevinden - 
is niet vooraf gegeven, maar wordt geconstitueerd door het rechtssysteem. Dat wil zeggen, deze mensen vormen slechts een eenheid, omdat ze allemaal een bepaalde juridische relatie met de rechtspersoon hebben. Tot de feitelijke organisatie van de gemeente kan men eventueel ook nog bepaalde mensen rekenen die een relevante feitelijke relatie hebben met de ambtsdragers en/of de ambtenaren (3). Naast mensen van vlees en bloed kan men in de empirische werkelijkheid ook nog allerlei zaken aanwijzen, die eveneens een bepaalde juridische relatie met de rechtspersoon hebben, zoals parken, openbare wegen, gebouwen, schilderijen, strooiwagens en uniformen. Ook de eenheid van deze zaken - die zich eveneens overal ter wereld kunnen bevinden - wordt geconstitueerd door het rechtssysteem. Ook zij vormen dus slechts een eenheid door de juridische relatie die ze met de rechtspersoon hebben. De mensen en de zaken in de empirische werkelijkheid die een bepaalde relatie met de rechtspersoon hebben, moeten uiteraard niet worden verward met de rechtspersoon zelf: die laat zich immers niet in de empirische werkelijkheid lokaliseren en aanwijzen. In tegenstelling tot natuurlijke personen, hebben rechtspersonen dus geen feitelijke component in de empirische werkelijkheid: het zijn louter namen binnen het rechtssysteem.

Net als de 'Gemeente Rotterdam' is ook het 'Koninkrijk der Nederlanden' niets anders dan een naam binnen het rechtssysteem. De Nederlandse staat is een species van het door het internationaal publiekrecht ingestelde genus 'staat'. Het internationaal publiekrecht kent aan alle individuele staten bepaalde bevoegdheden toe en bakent die tegelijkertijd in ruimtelijke zin af. Wat hier in ruimtelijke zin wordt afgebakend, is dus niet de staat zelf - dat is immers een naam - maar diens bevoegdheden. Het gaat bij deze ruimtelijke afbakening van de bevoegdheden van de staat verder niet om een tweedimensionaal stuk grond, maar om een driedimensionale ruimte, waartoe ook het luchtruim en eventuele mijnen en grotten onder de grond behoren. De door het internationaal publiekrecht toegekende en afgebakende bevoegdheden worden normaliter uitgeoefend door ambten en organen die krachtens nationaal publiekrecht zijn ingesteld. Tezamen vormen deze nationale organen niet een tweede rechtspersoon 'staat', maar de staatsinrichting. Het Nederlandse publiekrecht kent daarnaast nog wel zijn eigen publiekrechtelijke rechtspersonen, zoals provincies en gemeenten. Tezamen met de krachtens internationaal publiekrecht gecreëerde staat, worden deze krachtens nationaal publiekrecht gecreëerde rechtspersonen in artikel 2:1 BW erkend - en dus niet gecreëerd - als rechtspersonen in het Nederlandse privaatrecht. In artikel 51 Sr gebeurt hetzelfde voor het Nederlandse strafrecht. De rechtspersoon 'staat' - een naam binnen het rechtssysteem - moet uiteraard niet worden verward met de feitelijke voorwaarden voor de creatie van een staat: een grondgebied, een bevolking en een effectieve regering. ${ }^{26}$ Als naam binnen het rechtssysteem, is de staat niet vatbaar voor verdere ontleding, en net als alle andere rechtspersonen, kan ook deze rechtspersoon niet in de empirische werkelijkheid worden gelokaliseerd en aangewezen. Door het rechtssysteem te gebruiken als interpreta-

26 Ik laat de vraag of erkenning door andere staten een vierde voorwaarde is hier verder buiten beschouwing. 
tieschema van de empirische werkelijkheid, kunnen we in die werkelijkheid uiteraard wel allerlei mensen en zaken aanwijzen die een bepaalde relatie met deze rechtspersoon hebben.

Wanneer de nominalistische opvatting van de rechtspersoon in eerste instantie een zekere bevreemding opwekt, dan komt dat waarschijnlijk door het feit dat men in de afgelopen eeuwen bij de theorie van de rechtssubjecten veelvuldig heeft gezondigd tegen wat Kelsen het Reinheitspostulat heeft genoemd. Volgens dit methodologische postulaat moet de rechtstheoreticus de fundamentele begrippen van de rechtswetenschap zuiver en alleen in termen van het rechtssysteem definieren. Alle zaken die zich buiten het rechtssysteem bevinden, dienen daarom buiten beschouwing te blijven, tenzij het rechtssysteem daar zelf naar verwijst. Het rechtssysteem moet in dit verband in twee verschillende richtingen worden afgebakend. Ten eerste moet het rechtssysteem - als een systeem van normen - worden afgebakend ten opzichte van de empirische werkelijkheid. Daarnaast moet het rechtssysteem worden afgebakend ten opzichte van andere normatieve systemen - zoals morele en religieuze normatieve systemen - alsmede ten opzichte van politieke idealen en/of ideologieën.

Tegen de beide poten van dit Reinheitspostulat is met name bij de behandeling van de rechtspersoon 'staat' veelvuldig gezondigd. Zo wordt de staat in tal van beschouwingen vrijwel direct verward met de drie feitelijke voorwaarden voor de creatie van een staat: een grondgebied, een bevolking en een effectieve regering. Men begrijpt deze rechtspersoon in veel gevallen dus ten onrechte als een deel van de empirische werkelijkheid en stelt zich daarna pas de vraag hoe deze puur feitelijke drie-eenheid zich tot het rechtssysteem verhoudt. Ook tegen de tweede poot van het Reinheitspostulat is veelvuldig gezondigd. Zo is er een frappant verschil tussen de wijze waarop men de rechtspositie van de staat en de rechtspositie van de overige rechtspersonen behandelt. Terwijl men zich bij het vaststellen van de rechtspositie van een gemeente of een bv strikt houdt aan de formele rechtsbronnen - zoals de Gemeentewet en het BW - is het bij de behandeling van de rechtspositie van de staat bepaald geen uitzondering dat men plotseling de geschriften van Jean Bodin (1530-1596) of Max Weber (1864-1920) tevoorschijn tovert, om te betogen dat de staat 'soeverein' is of over een 'geweldsmonopolie' beschikt. Bij het vaststellen van de rechtspositie van de staat worden klassieke geschriften uit de politiek filosofische of sociologische literatuur dus plotseling behandeld alsof zij tot de formele bronnen van het positieve recht behoren. Door al dit soort van methodologische fouten wordt een 'zuivere' - dat wil zeggen strikt positiefrechtelijke - analyse van de rechts-persoon staat en diens rechts-positie vermengd en vertroebeld met allerlei zaken die zich buiten het rechtssysteem bevinden.

Deze vermenging van het rechtssysteem met andere domeinen van de werkelijkheid - en zelfs met de domeinen van de fictie en de mystiek, zoals we in de volgende paragraaf nog zullen zien - heeft geleid tot een groot aantal uiteenlopende opvattingen over wat een rechtspersoon nu precies is. Bij de rechtspersoon 'staat' wordt deze verwarring nog eens extra in de hand gewerkt door de semantische 
meerduidigheid van het woord 'staat'. Het woord 'staat' wordt namelijk niet alleen gebruikt in de betekenis van rechtspersoon, maar ook in de betekenis van grondgebied ('kuststaat', 'Afrikaanse staat'), bevolking ('multi-etnische staat', 'Arabische staat'), staatsvorm of staatsinrichting ('federale staat', 'gedecentraliseerde eenheidsstaat'), of nationaal rechtssysteem ('kapitalistische staten', 'communistische staten'). ${ }^{27} \mathrm{Bij}$ de theorie van de rechtssubjecten kan het uiteraard alleen maar gaan om de 'staat' als rechtspersoon, dat wil zeggen om de 'staat' als rechtssubject. Ter verdediging van de nominalistische theorie van de rechtspersoon, zal ik in het volgende deel de aanval inzetten op de alternatieve theorieën van de rechtspersoon.

\section{Deel II De alternatieve theorieën van de rechtspersoon}

\section{Overzicht van de alternatieve theorieën van de rechtspersoon}

In het eerste deel van deze bijdrage heb ik betoogd dat de rechtspersoon moet worden begrepen als een naam binnen het rechtssysteem, die fungeert als drager van rechten, plichten en bevoegdheden en als toerekeningspunt van menselijk gedrag. De rechtspersoon bestaat uitsluitend binnen het rechtssysteem en kan met mensen en zaken buiten het rechtssysteem hooguit een bepaalde juridische relatie hebben. Hoewel deze nominalistische opvatting van de rechtspersoon niet geheel en al nieuw lijkt te zijn, is de rechtspersoon bij mijn weten in de afgelopen eeuwen niet meer beschreven als een naam binnen het rechtssysteem. ${ }^{28}$ Sinds de

27 Door deze meerduidigheid van het woord 'staat' ligt ook de zogenaamde fallacy of ambiguity voortdurend op de loer. Zo werd in de recente discussie over het al dan niet afschaffen van de strafrechtelijke immuniteiten van publiekrechtelijke rechtspersonen meer dan eens betoogd dat de staat zichzelf zou vervolgen, wanneer het Openbaar Ministerie (een orgaan) de staat (een rechtspersoon) zou vervolgen. Zie bijv. Taru Spronken, 'Opheffen van de strafrechtelijke immuniteit van de Staat: bijten in eigen staart?,' NJB 1343 (2013): 1439.

28 In de door mij geraadpleegde literatuur trof ik slechts twee citaten aan - uit respectievelijk de dertiende en de vijftiende eeuw -die op een nominalistische theorie van de rechtspersoon lijken te wijzen. Het gaat bij deze citaten echter niet om nauwkeurig uitgewerkte theorieën van de rechtspersoon, maar veeleer om losse opmerkingen in concrete zaken. Von Gierke bespreekt ten eerste de opvatting van de Italiaanse canonist Sinibaldo dei Fieschi (1195-1254), beter bekend als de latere paus Innocentius IV. Volgens Innocentius konden rechtspersonen niet worden geëxcommuniceerd, omdat zij 'namen van het recht en niet van personen' zijn (nomina sunt iuris, et non personarum). Om deze reden achtte hij het dan ook onmogelijk dat een rechtspersoon zelf een overtreding zou kunnen begaan (impossibile est, quod universitas delinquat). Bij nadere beschouwing lijkt de door Innocentius verdedigde leer van de rechtspersoon echter meer op een variant van de fictieleer, dan op de door mij verdedigde nominalistische leer. Von Gierke beschouwde deze dertiende-eeuwse paus dan ook als de eerste representant van de fictieleer. Zie Otto von Gierke, Das Deutsche Genossenschaftsrecht. Dritter Band. Die Staats- und Korporationslehre des Alterthums und des Mittelalters und ihre Aufnahme in Deutschland (Berlijn: Weidmann, 1881), 279-81. Pollock en Maitland hebben daarnaast nog gewezen op het volgende citaat uit het zgn. Year Book van 1481: 'le corporacion de eux n'est que un nosme, que ne poit my estre vieu, et n'est my substance, e a ceo nosme ou corps est impossible de faire un tort.' Zie Year Book 21 Edw. IV.f.13 (Mich. pl. 4), aangehaald in Frederick Pollock en Frederic William Maitland, The History of English Law before the Time of Edward I, Vol. 1 (Cambridge: Cambridge University Press, 1923), 490, n8. 
hoogoplopende discussie over 'het wezen der rechtspersoon' in de negentiende eeuw is de rechtspersoon daarentegen wel omschreven als een organisme, een organisatie, een gepersonifieerd complex van normen, een complex van ambten en organen, een complex van vermogensrechtelijke rechten en plichten, een fictie, een abstractie of als een niet nader omschreven 'entiteit'. In deze paragraaf zal ik eerst een kort overzicht presenteren van de belangrijkste alternatieve theorieën van de rechtspersoon die tot nu toe zijn gepresenteerd. In de volgende paragraaf zal ik vervolgens proberen aan te tonen dat geen van deze theorieën de toets der kritiek kan doorstaan.

Om enige structuur aan te brengen in het debat over de aard van de rechtspersoon, zouden we op dit punt kunnen zeggen dat een rechtspersoon in abstracto slechts drie verschillende dingen kan zijn, namelijk: (1) een extra-systemische entiteit, die zich buiten het rechtssysteem bevindt, (2) een intra-systemische entiteit, die zich binnen het rechtssysteem bevindt, of (3) een hybride entiteit, die zich tegelijkertijd zowel binnen als buiten het rechtssysteem bevindt. Deze drie mogelijkheden sluiten elkaar wederzijds uit en zijn gezamenlijk uitputtend, zodat iedere mogelijke theorie van de rechtspersoon tot één van deze drie grondposities kan worden herleid. Op basis van deze driedeling zal ik in deze paragraaf vijf alternatieve theorieën van de rechtspersoon de revue laten passeren. Met de nominalistische theorie van de rechtspersoon erbij, komen we dan in totaal op een zestal concurrerende theorieën, die ik graag als volgt zou willen typeren:

\begin{tabular}{ll}
\hline Extra-systemisch & - de sociaal-biologische of organische leer \\
& - de sociologische leer \\
Hybride & - de sociologisch-juridische leer \\
& - de fictieleer \\
Intra-systemisch & - de leer van het (gepersonifieerde) normencomplex \\
& - de nominalistische leer \\
\hline
\end{tabular}

Bij de leer van het (gepersonifieerde) normencomplex, gaat het respectievelijk om Kelsens gelijkstelling van de staat met de nationale rechtsorde, Logemanns leer van de staat als ambtenorganisatie en de privaatrechtelijke doctrines van het collectieve vermogen en het (subjectloze) doelvermogen. Bij het hierna volgende overzicht gaat het mij niet zozeer om een chronologische reconstructie van het historische debat, maar veeleer om een systematische inventarisatie van de verschillende manieren waarop het begrip 'rechtspersoon' kan worden uitgelegd. Omdat de vijf alternatieve theorieën in principe nog op allerlei verschillende manieren nader kunnen worden ingekleurd - of met elkaar kunnen worden vermengd -, dienen de historische voorbeelden die ik hieronder zal aanhalen dan ook in de eerste plaats als illustraties van vijf mogelijke alternatieve theorieën van de rechtspersoon. Ik begin het overzicht van de alternatieve theorieën van de rechtspersoon met de theorieën die de rechtspersoon als een extra-systemische entiteit hebben gepresenteerd. 


\section{(a) De rechtspersoon als extra-systemische entiteit}

Een groot aantal beschouwingen over het begrip rechtspersoon verloopt volgens het volgende stramien. Men gaat ten eerste stilzwijgend uit van een extra-systemisch begrip van de rechtssubjecten: de subjecten van het recht bevinden zich allemaal buiten het recht en zijn daaraan 'onderworpen' (subjectum). Vervolgens onderscheidt men twee categorieën rechtssubjecten: natuurlijke personen en rechtspersonen. De natuurlijke persoon wordt daarna simpelweg gedefinieerd als een mens van vlees en bloed - dat wil zeggen als een biologische entiteit - waardoor de aandacht volledig op de empirische werkelijkheid gevestigd raakt. Naar analogie van de als mens gedefinieerde natuurlijke persoon, probeert men ten slotte de rechtspersoon te begrijpen als een groep mensen.

Deze analogie met de als mens gedefinieerde natuurlijke persoon is het verst doorgevoerd door de sociaal-biologische of organische leer. Volgens deze tamelijk krasse leer moet men de als 'rechtspersoon' aangeduide groep mensen in de empirische werkelijkheid namelijk begrijpen als een zelfstandig organisme. De Duitse rechtshistoricus Otto von Gierke (1841-1921) - die tegenwoordig wordt gezien als de belangrijkste exponent van deze leer - heeft in dit verband gesproken over een realer Gesammtperson. ${ }^{29}$ De sociaal-biologische zienswijze heeft echter veel oudere wortels. Zo sprak men volgens Kantorowicz in de karolingische tijd over de kerk als het 'lichaam van Christus' (corpus Christi) en over de geconsacreerde hostie als diens 'mystieke lichaam' (corpus mysticum). Halverwege de twaalfde eeuw waren deze twee uitdrukkingen echter van betekenis gewisseld, zodat nu niet langer de hostie, maar de kerk - dat wil zeggen de gemeenschap der gelovigen - als corpus mysticum Christi werd beschreven. ${ }^{30}$ Nog een eeuw later werd de theorie van de kerk als het mystieke lichaam van Christus uiteindelijk vervolmaakt door Thomas van Aquino (1225-1274). Om de continuïteit en de identiteit van de kerk tot aan de Dag des Oordeels te kunnen verklaren, betoogde de doctor angelicus dat het corpus Ecclesiae niet alleen de gelovigen op een bepaald moment in de geschiedenis omvatte, maar alle (potentiële) gelovigen uit zowel het heden, het verleden als de toekomst. ${ }^{31}$ In tegenstelling tot het natuurlijke lichaam van Christus, verschijnen de onderdelen van zijn mystieke lichaam dus niet allemaal tegelijkertijd, maar in een voortdurende opeenvolging, tot aan het einde der tijden. ${ }^{32}$

Naar analogie van deze opvatting van de kerk als het mystieke lichaam van Christus met Christus aan het hoofd, begon men in latere eeuwen eveneens te spreken over de staat als een (mystiek) lichaam met de koning aan het hoofd, waarbij het lichaam deze keer niet werd gevormd door de gelovigen, maar door de onderdanen. Binnen de sociaal-biologische stroming wordt de staat dan ook meestal

29 Otto von Gierke, Die Genossenschaftstheorie und die deutsche Rechtsprechung (Berlijn: Weidmann, 1887), 5.

30 Ernst Kantorowicz, The King's Two Bodies. A Study in Mediaeval Political Theory (Princeton, NJ: Princeton University Press, 1957), 194-206. De opvatting van de kerk als corpus Christi gaat uiteindelijk overigens terug op Paulus. Zie 1 Korintiërs 12.

31 Thomas van Aquino, Summa Theologiae, III, q. 8, a. 3: 'quia corpus Ecclesiae constituitur ex hominibus qui fuerunt a principio mundi usque ad finem ipsius.'

32 Kantorowicz, The King's Two Bodies, 308-10. 
gelijkgesteld met een volk - of beter: met een 'organische volksgemeenschap' die in de loop van de geschiedenis een soort quasi-biologisch proces doorloopt. Net als mensen, verschijnen de verschillende volkeren van de aarde op een goed moment op het wereldtoneel, alwaar zij in een proces van eeuwen gedijen en tot bloei komen, om vervolgens weer in verval te raken en te verdwijnen. Hoewel deze sociaal-biologische organismen zich niet als zodanig door mensen laten observeren, zouden zij volgens de aanhangers van deze leer wel beschikken over een eigen wil, een eigen weten en een eigen vermogen tot handelen - en zelfs, althans volgens sommigen, over een eigen gevoelsleven en een eigen sekse. Zo stelde de Zwitserse rechtsgeleerde Johann Kaspar Bluntschli (1808-1881) zich de vraag of de staat een man of een vrouw is. Zijn antwoord: 'Der Stat ist der Mann.' Volgens Bluntschli is de kerk daarentegen een vrouw, zodat hij op basis van dit sociaal-biologische sekseonderzoek tot de conclusie kwam dat de kerk ondergeschikt is aan de staat. ${ }^{33}$ Het nog steeds courante vocabulaire van 'openbare lichamen' met 'organen' - en de equivalenten daarvan in andere talen, zoals corps publique of body corporate - herinnert ons nog dagelijks aan deze sociaal-biologische zienswijze.

Wanneer men de analogie met de als mens gedefinieerde natuurlijke persoon niet zó ver wil doorvoeren als de aanhangers van de sociaal-biologische leer, dan komt men als vanzelf uit bij de sociologische leer. Volgens de sociologische leer is de rechtspersoon geen organisme, maar een organisatie: het is een georganiseerde groep mensen in de empirische werkelijkheid. De rechtspersoon wordt door deze leer dus gelijkgesteld - of zo men wil: verward - met de feitelijke organisatie van de rechtspersoon. Staatsvorming wordt binnen de sociologische stroming dan ook steevast begrepen als groepsvorming. Het verklaren van de eenheid van zo'n als rechtspersoon omschreven groep mensen - en het daarmee verband houdende probleem van inclusie en exclusie - is het belangrijkste theoretische probleem van de sociologische leer. Verschillende verklaringen voor de eenheid van de groep zijn in de loop der tijd voorgesteld.

Een eerste mogelijke verklaring voor de eenheid van de groep is dat de leden van de groep bijeengehouden worden door een eigen subsysteem van sociale - dat wil zeggen niet-juridische - normen. Aangezien men rechtspersonen in dat geval beter zou kunnen beschrijven als 'sociale instituties', heeft de Tsjechische rechtstheoreticus Ota Weinberger (1919-2009) deze variant van de sociologische leer wel betiteld als 'klassiek' of 'sociologisch institutionalisme', ter onderscheiding van het hierna nog te bespreken 'juridisch institutionalisme'. ${ }^{34}$ Een tweede verklaring voor de eenheid van de groep is dat alle leden van de groep een gemeenschappelijk doel zouden nastreven. De groep kan dan worden gepresenteerd als een 'teleologische eenheid' of als een 'doeleenheid'. Afhankelijk van het doel van een bepaalde groep, spreekt men dan vervolgens van een staat, een kerkgenootschap, een onderneming of een muziekvereniging. Dit is bijvoorbeeld de - expli-

33 Johann Kaspar Bluntschli, Allgemeine Statslehre. Band I (München: Cotta, 1868), 51.

34 Ota Weinberger, Recht, Institution und Rechtspolitik. Grundprobleme der Rechtstheorie und Sozialphilosophie (Stuttgart: Steiner, 1987), 151. 
ciet thomistische - leer van Van Nispen tot Sevenaer, die de staatsgemeenschap begrijpt als een 'eenheid van individuen, die geordend zijn op hun gemeenschappelijk doel'. Dit doel - het staatsdoel - is het 'algemeen welzijn', het 'volledig mensch-zijn, zoowel geestelijk als lichamelijk'. ${ }^{35}$ Een derde verklaring voegt hier vervolgens nog een gemeenschappelijk verleden aan toe. Typisch negentiendeeeuws is de gedachte van de 'natiestaat', waarbij de (vermeend) homogene volksgemeenschap niet alleen bijeengehouden wordt door een gemeenschappelijk verleden en een gedeelde taal en cultuur, maar ook door een collectieve wil om deze gemeenschappelijke erfenis in stand te houden en om in de toekomst vreedzaam met elkaar verder te leven. ${ }^{36}$ In een wat minder idyllische voorstelling van zaken legt men de nadruk daarentegen juist op pure machtsuitoefening, op oorlog en geweld. Staatsvorming ontstaat primair door externe vijanden die ertoe dwingen om een interne machtsorganisatie op te tuigen, die in staat is om belasting te heffen en een permanent leger op de been te houden. Vanuit deze invalshoek wordt de staat dan beschreven als een georganiseerde dwanggemeenschap of als de dominante (interne) machtsorganisatie. Beroemd in dit verband is de these van de Amerikaanse politicoloog Charles Tilly (1929-2008) over de staatsvorming in Europa: 'War made the state and the state made war.'37

Auteurs die uitgaan van een sociologisch georiënteerde opvatting van de rechtspersoon hebben er meestal geen enkele moeite mee om in het commune strafrecht een rechtspersoon als dader aan te wijzen. Zo heeft de strafrechtgeleerde Nico Jörg bijvoorbeeld betoogd dat een rechtspersoon op een zinvolle wijze een strafrechtelijk verwijt kan worden gemaakt en hij is daarbij uitgegaan van een sociologisch georiënteerde opvatting van de rechtspersoon: de rechtspersoon is volgens hem een 'sociale entiteit'. ${ }^{38}$ Bij zijn bespreking van de aard van deze sociale entiteit, refereert Jörg aan een sociologisch onderscheid tussen verschillende soorten groeperingen, namelijk 'groepen', 'sociale categorieën' en 'collectiviteiten'. Bij de rechtspersoon zou het gaan om een 'collectiviteit'. Deze collectiviteit heeft volgens Jörg een 'reëel, zij het niet tastbaar meta-fysisch bestaan'. ${ }^{39}$ De in eerste instantie als 'sociale entiteit' afgeschilderde rechtspersoon wordt vervolgens nog op een sociaal-biologische wijze nader ingekleurd. De rechtspersoon krijgt van Jörg namelijk een eigen bewustzijn, een eigen weten en een eigen wil toegedicht. Zijn uiteindelijke conclusie is dan ook dat de rechtspersoon niet alleen een sociale, maar zelfs een morele actor is, zodat de vaststelling dat een rechtspersoon zich

C.M.O (Carel) Van Nispen tot Sevenaer, De Rechtspersoon. Een studie over het wezen der rechtspersoon en deszelfs betekenis voor staats- en privaatrecht (Haarlem: H.D. Tjeenk Willink, 1936), 81-82. Later in dit werk beroept Van Nispen tot Sevenaer zich in dit verband ook nog expliciet op de aristotelische leer van de zgn. 'doeloorzaak' (causa finalis), zie 186-88.

36 Zie in dit verband met name Ernest Renan, Qu'est-ce qu'une nation? (Parijs: Calman Lévy, 1882), 28.

37 Charles Tilly, Coercion, Capital, and European States, AD 990-1990 (Cambridge, MA: Blackwell, 1990).

38 Nico Jörg, Strafbare rechtspersonen in Amerika. Corporaties en hun functionarissen in het Amerikaanse strafrecht in rechtsvergelijkend perspectief (Arnhem: Gouda Quint, 1990), 152.

39 Jörg, Strafbare rechtspersonen in Amerika, 152. 
verwijtbaar heeft gedragen volgens hem 'niet op principiële bezwaren kan stuiten'. ${ }^{40}$

De sociologische en de nominalistische leer staan hier lijnrecht tegenover elkaar. Volgens de nominalistische leer is een rechtspersoon immers geen 'sociale entiteit' die is toegerust met een supra-individueel bewustzijn en een eigen moreel besef, maar een naam binnen het rechtssysteem. De rechtspersoon is volgens deze leer dan ook geen zelfstandige sociale en morele actor, het is zelfs überhaupt geen actor. Het is een louter passief 'punt' binnen het rechtssysteem, waaraan het handelen en nalaten van mensen kan worden toegeschreven, maar dat zelf niet tot enig handelen in staat is. In tegenstelling tot de sociologische leer, ziet de nominalistische leer in de empirische werkelijkheid dan ook alleen maar individuele mensen. Het gedrag van meerdere individuele mensen kan aan één centraal toerekeningspunt binnen het rechtssysteem worden toegeschreven, maar uiteindelijk zijn het alleen de individuele mensen die in de empirische werkelijkheid in staat zijn tot handelen en nalaten. Om die reden kan men ook alleen maar individuele mensen op een zinvolle wijze een moreel verwijt maken. ${ }^{41}$

\section{(b) De rechtspersoon als hybride entiteit}

De sociologische leer van de rechtspersoon heeft de neiging om uit te monden in een hybride leer. Op een goed moment zal men immers toch het rechtssysteem in de analyse moeten betrekken, bijvoorbeeld wanneer men moet uitleggen waarom gezinnen en vriendengroepen geen rechtspersonen zijn, terwijl andere groepen dat wel zijn. Zodra een sociologische leer van de rechtspersoon een verwijzing naar het rechtssysteem opneemt, verandert zij in een sociologisch-juridische leer. Ook bij deze leer kan men verschillende varianten onderscheiden. Een veelvoorkomende variant is de opvatting dat de rechtspersoon een 'sociale entiteit' in de empirische werkelijkheid is, waaraan 'rechtspersoonlijkheid' is toegekend. Zo stellen De Corte en De Groote: 'De rechtspersoon is een sociale entiteit bekleed met rechtspersoonlijkheid', het is 'een instelling, stichting en groepering van individuen of kapitalen die in rechte erkend zijn als titularis van bepaalde rechten en verplichtingen. Ze bezitten rechtspersoonlijkheid'. ${ }^{42}$ De 'rechtspersoonlijkheid' die deze sociale entiteiten 'bezitten', wordt meestal getypeerd als de capaciteit om drager van rechten, plichten en bevoegdheden te zijn of als de bekwaamheid om aan het rechtsverkeer deel te nemen. ${ }^{43} \mathrm{Bij}$ een andere variant van deze leer abstraheert men van de concrete individuen van de groep, zodat het recht deze

40 Jörg, Strafbare rechtspersonen in Amerika, 158.

41 De problematiek van het strafrechtelijke daderschap van de rechtspersoon wordt nader uitgewerkt in mijn binnenkort te verschijnen artikel 'Dood door schuld "begaan" door de rechtspersoon. De lege stoel van de verdachte.'

42 Rogier De Corte en Bertel de Groote, Handboek Civiel Recht (Brussel: Groep de Boeck, 2008), 181 en 184.

43 De Corte en De Groote, Handboek Civiel Recht, 181-82. Vergelijk ook Boleslaw Boczek, International Law: A Dictionary (Lanham, MD: Scarecrow Press, 2005), 75: 'International legal personality is a concept referring to the status of having personality under international law, that is, possessing rights and duties governed by this law, and, in general, a capacity to act on the international plane (...).' 
als abstractie gedachte 'groep' of 'eenheid' als rechtssubject kan laten optreden. Dit is bijvoorbeeld de leer van Paul Scholten (1875-1946): 'De corporatie-rechtspersoon is de tot enig doel rechtens verbonden dan wel toevallig krachtens historische ontwikkeling samengekomen groep van mensen, die zich als zelfstandig subject van rechten vertoont, door het recht als eenheid wordt behandeld. ${ }^{44}$ In zijn polemiek met de fictieleer kwalificeert Scholten zijn eigen leer als de 'leer van de juridische realiteit'. ${ }^{45}$ Deze kwalificatie - die is ontleend aan het proefschrift van Philippus Houwing (1897-1985) - is misleidend, aangezien Scholten de rechtspersoon niet begrijpt als een zuiver juridische entiteit, maar als een hybride entiteit. Het gaat volgens hem immers primair om een 'groep van mensen' die zich pas in tweede instantie 'als zelfstandig subject van rechten vertoont'.

Dat de sociologische leer van de rechtspersoon de neiging heeft om uit te monden in een hybride leer, is ook goed te zien bij auteurs die hun analyse van de staat beginnen met een zuiver sociologische opvatting van de staat. Een dergelijke staatsopvatting leidt onvermijdelijk tot het zogenaamde dualisme van recht en staat, waarbij de staat - begrepen als een puur feitelijke machtsorganisatie 'voor', 'buiten' of 'boven' het recht moet worden geplaatst. In haar preadvies over de strafrechtelijke immuniteit van de staat, lijkt Van Sliedregt dit dualisme van recht en staat in eerste instantie volledig te omarmen, wanneer zij spreekt over de 'soevereine positie van de staat als drager van de rechtsorde'. ${ }^{46}$ Onder verwijzing naar Jean Bodin, typeert zij de zogenaamde 'strikte soevereiniteitsgedachte' als volgt: 'De Staat gaat vooraf aan het recht en de rechtsorde. Als bron van alle recht is de Staat als zodanig buiten het door hem gecreëerde recht te plaatsen. ${ }^{47}$ Deze extra-systemische staat - die aan het recht voorafgaat - beschikt volgens Van Sliedregt ook over het geweldsmonopolie en kan daarom worden beschreven als de 'drager van de rechtsorde'. ${ }^{48}$ Omdat het echter niet goed mogelijk is om de rechtspersoon 'staat' geheel en al buiten het door hemzelf gecreëerde recht te houden, stuit zij vervolgens op 'de anomalie van de Staat als drager van en deelnemer aan de rechtsorde'. ${ }^{49}$ Doordat we de staat in tweede instantie dus zowel binnen als buiten het recht moeten zoeken, legt Van Sliedregt uiteindelijk geen zuiver sociologische, maar een hybride staatsopvatting aan haar preadvies ten grondslag. Op basis van deze hybride staatsopvatting acht zij strafvervolging van de (binnen het recht staande) staat zowel mogelijk als wenselijk, maar ziet zij een uitzonderingspositie voor de staat op het gebied van de strafexecutie, vanwege het aan de (buiten het recht staande) staat toekomende geweldsmonopolie. ${ }^{50}$

44 Scholten, 'Theoretische beschouwing,' 20.

45 Scholten, 'Theoretische beschouwing,' 8. Zie Philippus Houwing, Subjectief recht, rechtssubject, rechtspersoon (Zwolle: W.E.J. Tjeenk Willink, 1939), 118-29.

46 Elies van Sliedregt, 'Immuniteit van de Staat: de houdbaarheid voorbij?,' in Immuniteiten. Het recht opzijgezet? (Handelingen Nederlandse Juristen-Vereniging 2013-I) (Deventer: Kluwer, 2013), 192.

47 Van Sliedregt, 'Immuniteit van de Staat,' 192-93.

48 Van Sliedregt, 'Immuniteit van de Staat,' 193.

49 Van Sliedregt, 'Immuniteit van de Staat,' 193.

50 Van Sliedregt, 'Immuniteit van de Staat,' 195 en 202. 
De beroemdste hybride staatsopvatting staat op naam van de Duitse socioloog Max Weber (1864-1920). Volgens Weber is de moderne staat een juridisch georganiseerd 'heerschappijverband' (Herrschaftsverband), dat binnen een bepaald gebied met succes het monopolie op het legitieme gebruik van fysiek geweld heeft weten te claimen. ${ }^{51}$ Deze hybride staatsopvatting is met name populair in de sociologie, de politicologie en de leer der internationale betrekkingen. In de rechtswetenschap staat de meest invloedrijke hybride staatsopvatting echter op naam van de Duitse staatsrechtgeleerde Georg Jellinek (1851-1911). Volgens Jellineks zogenaamde Zwei Seiten-theorie van de staat, heeft de staat zowel een 'sociale' als een 'juridische zijde': de staat is dus tegelijkertijd 'half feit' en 'half recht'. De sociale zijde van de staat bestaat volgens Jellinek vervolgens weer uit drie zogenaamde Elementen, namelijk: een Staatsgebiet, een Staatsvolk en een Staatsgewalt. ${ }^{52}$ Deze zogenaamde Drei Elementen-Lehre van de staat is de directe inspiratiebron geweest voor de opstellers van de Montevideo Convention on the Rights and Duties of States uit 1933, die in het huidige volkenrecht wordt gezien als de locus classicus met betrekking tot de feitelijke voorwaarden voor de creatie van een staat. ${ }^{53}$ Artikel 1 van de Montevideo Convention luidt als volgt: 'The state as a person of international law should possess the following qualifications: (a) a permanent population; (b) a defined territory; (c) government; and (d) capacity to enter into relations with the other states.' De eerste drie criteria worden tegenwoordig algemeen erkend als internationaal gewoonterecht met betrekking tot de creatie van een staat. Criterium (d) wordt daarentegen door de meeste auteurs niet gezien als een extra voorwaarde voor de creatie van een staat, maar als een rechtsgevolg van die creatie.

De door Jellinek ontwikkelde Drei Elementen-Lehre is via de Montevideo Convention buitengewoon invloedrijk geworden in de twintigste-eeuwse rechtswetenschap. Zijn Zwei Seiten-theorie wordt daarbij echter lang niet altijd overgenomen. In tal van handboeken wordt de staat namelijk niet als een hybride, maar als een zuiver extra-systemische entiteit gepresenteerd, doordat men de feitelijke voorwaarden voor de creatie van deze rechtspersoon gelijkstelt met de rechtspersoon zelf. Van Jellineks Zwei Seiten blijft dan dus slechts de sociale zijde over. Zo geeft ook de befaamde Nederlandse volkenrechtsgeleerde Peter Kooijmans (1933-2013) een sociologisch-geografische definitie van de staat, wanneer hij onder verwijzing naar de Montevideo Convention de staat definieert als een 'territoriaal bepaalde gezagseenheid'. ${ }^{54}$ De rechtspersoon 'staat' wordt vervolgens

51 In Webers eigen woorden: 'der moderne Staat [ist] ein anstaltsmäßiger Herrschaftsverband (...), der innerhalb eines Gebietes die legitime physische Gewaltsamkeit als Mittel der Herrschaft zu monopolisieren mit Erfolg getrachtet hat und zu diesem Zweck die sachlichen Betriebsmittel in der Hand seiner Leiter vereinigt (...).' Max Weber, Wirtschaft und Gesellschaft. Grundriß der verstehenden Soziologie (Studienausgabe), (Tübingen: Mohr Siebeck, [1921/22] 1980), 822.

52 Georg Jellinek, Allgemeine Staatslehre (Darmstadt: Wiss. Buchgesellschaft [1900] 1960), 11 en 136 e.v.

53 Peter Malanczuk, Akehurst's Modern Introduction to International Law (Londen: Routledge, 1997), 75. Thomas D. Grant, 'Defining Statehood: The Montevideo Convention and its Discontents,' Columbia Journal of Transnational Law 37 (1998/99): 416.

54 Peter Kooijmans, Internationaal publiekrecht in vogelvlucht (Deventer: Kluwer, 2008), 26. 
expliciet voorgesteld als een puur feitelijke drie-eenheid in de empirische werkelijkheid: 'Voldoet een entiteit aan de drie feitelijke criteria, dan is het een staat (...). ${ }^{55}$

De tweede hoofdvariant van de hybride leer - de fictieleer - begint haar analyse van de rechtspersoon eveneens met de als mens van vlees en bloed gedefinieerde natuurlijke persoon. In tegenstelling tot de sociologisch georiënteerde theorieën, eindigt de fictieleer echter niet met een groep mensen in de empirische werkelijkheid, maar met een fictief persoon. Aan de fictieleer is sinds de negentiende eeuw de naam van de stichter van de historische Rechtsschule verbonden: Friedrich Carl von Savigny (1779-1861). ${ }^{56}$ Volgens Von Savigny genieten in beginsel alleen natuurlijke personen rechtsbekwaamheid (Rechtsfähigkeit), omdat de rechtsbekwaamheid aanknoopt bij de wilsbekwaamheid (Willensfähigkeit). ${ }^{57}$ Alleen de mens is wilsbekwaam en het is niet mogelijk om een nieuwe, met een eigen wil begiftigde entiteit in het leven te roepen door zich met andere mensen in een groep te verenigen. De wil van natuurlijke personen kan volgens Von Savigny echter wel worden toegerekend aan een fictief persoon - een persona ficta - zodat het probleem van de wilsbekwaamheid in principe kan worden ondervangen. Niet iedere willekeurige fictieve persoon is echter ook meteen een rechtspersoon. Om als rechtspersoon te kunnen fungeren, moet de fictieve persoon daarom eerst nog door het positieve recht met rechtsbekwaamheid worden toegerust. Volgens Von Savigny moet de fictieve persoon daarom altijd door de autoriteiten van het positieve recht worden gecreëerd, of in ieder geval worden erkend. Hoe deze creatie of erkenning precies zijn beslag krijgt in het positieve recht, wordt bij de aanhangers van de fictieleer helaas nooit helemaal duidelijk. ${ }^{58}$ Wat wel duidelijk wordt, is dat zij de rechtspersoon begrijpen als een hybride entiteit: de rechtspersoon is 'half fictie' en 'half recht'. Aangezien een louter gefingeerd persoon niet in staat is tot zelfstandig denken, willen en handelen, zag Von Savigny voor de rechtspersoon geen rol weggelegd in het strafrecht. ${ }^{59}$ Dit was ook de visie van de Nederlandse strafwetgever van 1881: 'Een strafbaar feit kan alléén worden gepleegd door den

55 Kooijmans, Internationaal publiekrecht, 26.

56 Von Savigny's verdediging van de fictieleer was het startschot voor het negentiende-eeuwse debat over de aard van de rechtspersoon. Zoals hierboven reeds vermeld, zou zijn grote tegenvoeter Von Gierke later in die eeuw echter paus Innocentius IV als de eerste vertegenwoordiger van de fictieleer aanwijzen. Zie Von Gierke, Das Deutsche Genossenschaftrecht, 279. Cf. Maximilian Koessler, 'The Person in Imagination or Persona Ficta of the Corporation,' Louisiana Law Review 9 (1949/4): 437.

57 Friedrich Carl von Savigny, System des heutigen römischen Rechts, Band I (Berlijn: Veit, 1840), 7.

58 Philippus Houwing, de belangrijkste vertegenwoordiger van de fictieleer in Nederland, beschrijft de 'juridische zijde' van de fictieve rechtspersoon als een bundel rechtsgevolgen: 'De voorstelling rechtspersoon is de voorstelling van dezen - in de stoffelijke werkelijkheid niet bestaanden - persoon. Haar inhoud wordt volledig bepaald door de rechtsgevolgen, die het recht aan de fictie, dat er in de werkelijkheid een persoon bestaan zou, verbindt.' Houwing, Subjectief recht, rechtssubject, rechtspersoon, 58.

59 Von Savigny, System des heutigen römischen Rechts, Band II, 312. 
natuurlijken persoon. De fictie der regtspersoonlijkheid geldt niet op het gebied van het strafregt.' 60

\section{(c) De rechtspersoon als intra-systemische entiteit}

De laatste groep theorieën die ik hier zal bespreken probeert de rechtspersoon zuiver en alleen in termen van het rechtssysteem te begrijpen. Deze theorieën begrijpen de rechtspersoon allemaal als een complex van normen - of als de personificatie van zo'n complex van normen - maar ze verschillen in de uitwerking van dit idee. Het gaat respectievelijk om Kelsens gelijkstelling van de staat met de nationale rechtsorde, Logemanns leer van de staat als ambtenorganisatie en de privaatrechtelijke doctrines van het collectieve vermogen en het (subjectloze) doelvermogen. De leer van Kelsen is van deze drie de meest algemene, maar wellicht ook de minst alledaagse. Omdat zijn leer ook van grote invloed is geweest op de staatsopvatting van Logemann, sta ik er iets uitvoeriger bij stil.

Kelsen verdeelt de verschillende wetenschappen in causale wetenschappen en normatieve wetenschappen. De causale wetenschappen - zoals natuurkunde, biologie en sociologie - proberen de empirische werkelijkheid te begrijpen op basis van het principe van causaliteit. De proposities die deze wetenschappen formuleren - de zogenaamde 'natuurwetten' - geven daarom uitdrukking aan de relatie tussen oorzaak en gevolg, bijvoorbeeld: 'als metaal wordt verhit, dan zet het uit'. De normatieve wetenschappen bestuderen daarentegen normatieve systemen. $\mathrm{Zij}$ bestuderen niet wat er daadwerkelijk gebeurt wanneer een bepaald feit zich in de werkelijkheid voordoet, maar wat er volgens een bepaald normatief systeem moet of mag gebeuren, wanneer dat feit zich voordoet. Dit normatieve 'gevolg' is geen causaal gevolg, maar een gevolg dat door een bepaald normatief systeem aan het feit wordt 'vastgeknoopt' of - zoals Kelsen het zelf zegt - 'toegerekend'. De proposities die de normatieve wetenschappen formuleren, geven daarom uitdrukking aan dit principe van toerekening (Zurechnung). Bijvoorbeeld: 'als iemand opzettelijk brand sticht, dan moet of mag de rechter een straf opleggen', of 'als iemand een vijand heeft, dan moet hij van die vijand houden'. Volgens Kelsen is het onmogelijk dat causale en normatieve wetenschappen hetzelfde object van studie hebben: de inhoud van normatieve systemen is immers geen onderdeel van causale ketens en er bestaan geen normatieve systemen die causaal bepaald zijn. In de wetenschap hebben we dus ófwel met het Sein, ófwel met het Sollen te maken en nooit met een mengvorm. Op basis van deze boedelscheiding verwerpt Kelsen de hybride Zwei-Seiten-theorie van zijn leermeester Jellinek als een uitvloeisel van diens 'kennistheoretische naïviteit'. ${ }^{61}$

Het probleem van de rechtspersoon valt volgens Kelsen binnen het domein van de rechtswetenschap en zal daarom zuiver en alleen in termen van het rechtssys-

60 MvT art. 51 (oud) Sr, in H.J. Smidt en J.W. Smidt, Geschiedenis van het Wetboek van Strafrecht. Volledige verzameling van regeeringsontwerpen, gewisselde stukken, gevoerde beraadslagingen, enz. (Eerste Deel), (Haarlem: H.D. Tjeenk Willink, 1891), 50.

61 Hans Kelsen, Der soziologische und der juristische Staatsbegriff. Kritische Untersuchung des Verhältnisses von Staat und Recht (Tübingen: Mohr (Paul Siebeck), 1922), 106. 
teem moeten worden opgelost. Zijn eigen oplossing voor dit probleem is dat de rechtspersoon een gepersonifieerd complex van normen is. Deze tamelijk opmerkelijke opvatting vindt zijn oorsprong in het zogenaamde Staatswillenspositivismus, dat in Kelsens formatieve jaren dominant was in Duitsland. Binnen deze stroming werd de staat voorgesteld als een 'persoon' en de inhoud van het recht - met name het Sollen - als de 'wil' van deze staatspersoon. Op basis van deze zienswijze kon een rechtsregel dan als volgt worden gereconstrueerd: 'als er een strafbaar feit is gepleegd, dan "wil" de staatspersoon dat er een straf wordt opgelegd.' Kelsens gedachtegang lijkt nu als volgt te zijn gegaan: wanneer we alle normen van de nationale rechtsorde op een dergelijke wijze reconstrueren en bijeennemen, dan zouden we kunnen zeggen dat 'de wil van de staatspersoon' precies samenvalt met 'de inhoud van de nationale rechtsorde'. Wanneer we ons vervolgens ontdoen van het antropomorfe spreken over de staat als een 'persoon' die begiftigd is met een 'wil', dan verschijnt het woord 'staat' als de uitdrukking voor de eenheid van de nationale rechtsorde. ${ }^{62}$ Onder invloed van het toenmalige staatswil-positivisme, komt Kelsen dus uiteindelijk tot de conclusie dat de staat niets anders is dan de nationale rechtsorde - of, in Herrera's vermakelijke parafrase van deze zogenaamde Identitätsthese: 'L'Etat, c'est le droit.' ${ }^{\text {'63 }}$

Hoewel Kelsen Jellineks Zwei Seiten-theorie op methodologische gronden verwerpt, neemt hij wel diens Drei Elementen-Lehre over, al voegt hij daar vervolgens nog wel het element 'tijd' als een vierde element aan toe. Omdat Kelsen de termen 'staat' en 'nationale rechtsorde' als synoniemen begrijpt, probeert hij deze vier elementen van de staat vervolgens echter te herdefiniëren in termen van de nationale rechtsorde. Zo presenteert hij het Staatsgebiet als het 'ruimtelijke geldingsbereik' (räumliche Geltungsbereich) van de nationale rechtsorde en het Staatsvolk als het 'persoonlijke geldingsbereik' (personale Geltungsbereich). ${ }^{64}$ Ook voor het hoofd van de Weense rechtstheoretische school heeft de rechtspersoon 'staat' dus nog een zekere extensie in ruimte en tijd, zij het dat dit nu een zuiver normatieve extensie is.

In tegenstelling tot de nominalistische leer, begrijpt Kelsen de rechtspersoon 'staat' dus niet als een individueel persoonlijk element - een naam - binnen het volkenrecht, maar als het geheel van alle nationale rechtsnormen, dat wil zeggen als een gigantisch conglomeraat van persoonlijke, normatieve, materiële, ruimtelijke en temporele elementen. Om toch bij de 'persoon' uit te komen, grijpt Kelsen naar het hulpmiddel van de personificatie. De rechts-persoon 'staat' wordt door

62 Hans Kelsen, 'Vorrede' bij de tweede editie van Hauptprobleme der Staatsrechtslehre entwickelt aus der Lehre vom Rechtssatze (Tübingen: Mohr (Paul Siebeck), 1923); onveranderde herdruk (Aalen: Scientia, 1984), X.

63 Carlos Miguel Herrera, La philosophie du droit de Hans Kelsen (Québec: Les Presses de l'Université de Laval, 2004), 43.

64 Kelsen, $R R$ 1960, §41(a), 291. Dit herdefiniëren van de elementen van de staat in termen van de nationale rechtsorde gebeurt overigens wel op een nogal ongelukkige wijze, omdat Kelsen de term Geltungsbereich - of sphere of validity - de ene keer gebruikt in de zin van bevoegdheid of jurisdictie (bijv. 'territoriale jurisdictie') en de andere keer in de zin van het toepassingsbereik van nationale rechtsnormen. 
hem namelijk gepresenteerd als de personificatie van de nationale rechtsorde. Die personificatie ontstaat wanneer we menselijk gedrag toeschrijven aan de nationale rechtsorde en over de staat spreken alsof het een handelend wezen is: 'de staat voert oorlog', 'de staat handhaaft het recht', 'de staat zorgt voor de armen' enzovoort. ${ }^{65}$ Kelsen heeft op zich geen bezwaar tegen deze personificatie van de nationale rechtsorde, zolang we ons van die personificatie maar terdege bewust blijven en niet ook nog eens overgaan tot een reïficatie van de nationale rechtsorde. De staat is immers geen daadwerkelijk bestaand superorganisme - geen Makroanthropos - zoals de aanhangers van de door hem zo verfoeide sociaal-biologische leer ons hebben willen doen geloven.

Naar analogie van zijn opvatting van de rechtspersoon 'staat', begrijpt Kelsen vervolgens ook alle andere rechtssubjecten. Zo presenteert hij de privaatrechtelijke rechtspersoon als de personificatie van een subsysteem van rechtsnormen, namelijk als de personificatie van het statuut van zo'n rechtspersoon. ${ }^{66}$ Ook het orgaan-begrip wordt op deze wijze uitgelegd: een 'orgaan' van een rechtspersoon is een complex (of bundel) van rechten, plichten en bevoegdheden. ${ }^{67}$ Zelfs de 'natuurlijke persoon' moeten we van Kelsen begrijpen als de personificatie van een subsysteem van normen, dat in dit geval is samengesteld uit de normen die op één bepaald individu van toepassing zijn. Zo bezien, aldus Kelsen, zijn de zogenaamde 'natuurlijke' personen dus in feite ook 'rechts'-personen. In beide gevallen gaat het namelijk om constructies van de rechtswetenschap, die worden gevormd door het isoleren en personifiëren van met elkaar samenhangende rechtsnormen. De rechtswetenschap beschrijft deze constructies met behulp van de begrippen 'natuurlijke persoon' en 'rechtspersoon', zodat we deze begrippen volgens Kelsen moeten begrijpen als 'hulpbegrippen' (Hilfsbegriffe) van de rechtswetenschap. ${ }^{68}$ Een 'rechtspersoon' is volgens deze analyse dus geen apart en zelfstandig onderdeel van het rechtssysteem, noch een entiteit in de empirische werkelijkheid, maar een door de rechtswetenschap geproduceerde constructie. ${ }^{69}$

De leer van de Nederlandse politicus en staatsrechtgeleerde Johann Logemann (1892-1969) - die ik hier zal opvoeren als representant van het zogenaamde juridisch institutionalisme ${ }^{70}$ - is expliciet geënt op de leer van Kelsen. Ook Logemann begrijpt de rechtspersoon 'staat' als de personificatie van een complex van normen. In tegenstelling tot Kelsen, neemt hij als het substraat van deze personificatie echter niet de gehele nationale rechtsorde, maar slechts de institutionele structuur van het publiekrecht. Voor Logemann is de staat primair organisatie. ${ }^{71}$ Anders dan bij het sociologisch institutionalisme, moeten we deze organisatie nu niet begrijpen als een door sociale normen bijeengehouden feitelijk verband van 
mensen, maar als een 'verband van functies', dat wil zeggen als een 'groep van ambten': de staat is de personificatie van de ambtenorganisatie. ${ }^{72}$ De rechtspersoon 'staat' wordt door deze leer dus gelijkgesteld - of zo men wil: verward - met de organen van de staat.

Logemann volgt Kelsen op de voet, wanneer hij een 'ambt' definieert als de 'personificatie [van] bevoegdheden en plichten van bepaald gequalificeerde mensen, gekoppeld aan een overdracht van qualiteit naar bepaalde eigen regels'. ${ }^{73}$ Verder betoogt hij met Kelsen dat de samenhang tussen deze ambten een normatieve samenhang is en dat de personificatie van de ambtenorganisatie slechts mogelijk, maar niet noodzakelijk is. Het motief om tot deze personificatie over te gaan, is volgens Logemann tweeledig. In het volkenrecht bestaat er ten eerste behoefte aan de vastlegging van de identiteit van de staat, in het rechtsverkeer met andere staten. In het nationale recht bestaat er daarnaast behoefte aan de eenheid van de staat, in het rechtsverkeer met de mensen voor wie zijn gezag geldt. ${ }^{74}$ Voor zover Logemann de staat begrijpt als de personificatie van de ambtenorganisatie, en een ambt als de personificatie van plichten en bevoegdheden, treffen we hier dus de figuur van de dubbele personificatie aan: de staat als een gepersonifieerde personificatie. Dat de zaak wel erg complex wordt wanneer men ook nog de ambtenorganisaties van de provincies en de gemeenten in deze constructie wil verdisconteren, constateert ook Logemann zelf, wanneer hij in 1947 schrijft: 'Om de moeilijkheid te doen gevoelen aan een ons toch zeer vertrouwde constructie, releveer ik hier slechts, dat de persoon van het ene Rijk der Nederlanden de personen van elf provincies en van ruim duizend gemeenten geacht wordt te bevatten, zonder dat hij de personificatie is van hun samenwerking. ${ }^{75}$

De opvatting dat de publiekrechtelijke rechtspersoon 'staat' gelijkgesteld kan worden met (de personificatie van) de publiekrechtelijke ambtenorganisatie - dat wil zeggen met de staatsinrichting - heeft vooral weerklank gevonden bij de op het publiekrecht georiënteerde juristen. Zo definieert Kortmann - in directe navolging van Logemann - de staat als een in externe verhoudingen onafhankelijk, door het recht geregeld complex van ambten, die in een rechtens geregelde verhouding tot elkaar en tot de onderdanen staan'. ${ }^{76}$ In zijn noot onder het Volkel-arrest, spreekt Corstens - onder verwijzing naar Kortmann - over de staat als een 'orga-

72 Logemann, Over de theorie van een stellig staatsrecht, 76-77.

73 Logemann, Over de theorie van een stellig staatsrecht, 77.

74 Logemann, Over de theorie van een stellig staatsrecht, 77.

75 Logemann, Over de theorie van een stellig staatsrecht, 77 (cursivering in het origineel).

76 C.A.J.M. (Tijn) Kortmann e.a., Constitutioneel recht (Deventer: Kluwer, 2012), 7 (cursivering toegevoegd). Ook in Van der Pot/Donner wordt Logemann met instemming aangehaald: 'LOGEMANN heeft iets heel wezenlijks getroffen, toen hij de staat een ambtenorganisatie noemde.' L. Prakke, J.L. de Reede, G.J.M. van Wissen, Van der Pot/Donner. Handboek van het Nederlandse Staatsrecht (Deventer: W.E.J. Tjeenk Willink, 2001), 151. Uit Van der Pot/Donner zelf valt overigens geen eenduidig staatsbegrip te distilleren, aangezien men daar tal van juridische, sociologische en politiek-filosofische benaderingen van de staat door elkaar heen laat lopen. Zo treft men nog geen twee regels na de instemming met Logemann de volgende exclamatie aan: 'De staat, dat zijn de dijken!' 
nisatievorm van een samenleving', een 'diffuse, complexe en grote organisatie', die 'verkokerd' is. ${ }^{77}$ De Commissie-Roelvink - die in 2002 adviseerde over de eventuele opheffing van de strafrechtelijke immuniteiten van publiekrechtelijke rechtspersonen - beschreef de staat als een 'abstractie (...) waarachter een veelheid aan instanties en organen schuilgaat'. De commissie achtte deze 'abstracte entiteit' geen geschikt aanknopingspunt voor strafrechtelijke vervolging en stelde daarom voor om de staat 'op te splitsen'. ${ }^{78}$

De laatste groep theorieën die de rechtspersoon als een complex van normen heeft beschreven, presenteert de rechtspersoon niet als een complex van publiekrechtelijke ambten en organen, maar als een complex van vermogensrechtelijke rechten en plichten. Volgens de doctrines van het collectieve vermogen of het (subjectloze) doelvermogen is de rechtspersoon namelijk een bepaald soort vermogen. Dit vermogen wordt gecontrasteerd met het vermogen van natuurlijke personen door het nader te kwalificeren als een collectief vermogen of - in het geval van de stichting - als een (subjectloos) doelvermogen. ${ }^{79}$ Aangezien namen zoals 'Hartstichting' en 'Nierstichting' in de ogen van deze leer dus moeten worden begrepen als namen die men aan privaatrechtelijke vermogens heeft gegeven, heeft Meijers deze leer ook wel de 'nominalistische' leer genoemd. ${ }^{80}$ Deze privaatrechtelijke doctrines moeten om die reden uiteraard niet worden verward met de door mij verdedigde nominalistische leer. Volgens deze privaatrechtelijke doctrines gaat het bij de rechtspersoon namelijk niet om een aparte categorie van rechtssubjecten, maar om specifieke vormen van eigendom. Om voor de hand liggende redenen hebben deze theorieën vooral aanhang gevonden onder civilisten. ${ }^{81}$

\section{Kritiek op de alternatieve theorieën van de rechtspersoon}

$\mathrm{Nu}$ we de alternatieve theorieën van de rechtspersoon de revue hebben laten passeren, is het tijd om deze tegenkandidaten eens wat steviger aan de tand te voelen door ze aan een aantal tests te onderwerpen. Voor dat doeleinde heb ik een aantal algemene kenmerken van de rechtspersoon bijeengebracht, die - naar ik meen door de meeste juristen zullen worden geaccepteerd. De vraag is nu in hoeverre die alternatieve theorieën van de rechtspersoon een adequate verklaring kunnen bieden voor deze kenmerken. Ik zal deze kenmerken eerst nog even kort toelich-

77 HR 25 januari 1994, NJ 1994/598, m.nt. Corstens (Volkel). De Hoge Raad bepaalde in dit arrest dat de Nederlandse staat volledige strafrechtelijke immuniteit geniet.

78 Rapport Commissie-Roelvink (Den Haag: 2002), 5 en 26. (online beschikbaar: https://www.recht. nl/doc/rapport_strafrechtelijke_aansprakelijkheid_staat.pdf).

79 Deze opvattingen van de rechtspersoon zijn meestal nauw verweven met een bepaalde opvatting van het begrip 'subjectief recht'. Zie voor een uitvoerige bespreking: Houwing, Subjectief recht, rechtssubject, rechtspersoon, 66-106.

80 Eduard Meijers, 'De beteekenis van het probleem der rechtspersoonlijkheid voor de praktijk,' WPNR 3285 (1932): 570.

81 Als de belangrijkste vertegenwoordigers van deze leer worden meestal Rudolf von Jhering (1818-1892) en Marcel Planiol (1853-1931) genoemd. In Nederland werd de theorie verdedigd door Willem Molengraaff (1858-1931). Zie voor een uitvoerige bespreking: Houwing, Subjectief recht, rechtssubject, rechtspersoon, 85-106. 
ten en ze daarna gebruiken in mijn kritiek op de hierboven besproken theorieën. Het gaat om het volgende lijstje:

1 Onstoffelijkheid

2 Creatie en ontbinding door rechtshandeling

3 Diversiteit tussen de genera en gelijkheid van de species

4 Continuïteit met behoud van identiteit

5 Drager van rechten en plichten

6 Toerekeningspunt van menselijk gedrag

Het eerste kenmerk van rechtspersonen is dat zij zich niet in de empirische werkelijkheid kunnen vertonen. Zo zijn vrijwel alle juristen het er wel over eens dat een rechtspersoon zich niet zélf in een rechtszaal kan vertonen en dat het onmogelijk is om een rechtspersoon in de gevangenis op te sluiten. Het gaat in deze gevallen niet om een praktische onmogelijkheid - die men eventueel zou kunnen ondervangen door bijvoorbeeld grotere rechtszalen en gevangenissen te bouwen maar om een (onto)logische onmogelijkheid: rechtspersonen zijn 'onstoffelijk'.

Een tweede kenmerk van rechtspersonen is dat ze in principe naar believen kunnen worden gecreëerd en ontbonden. Wanneer er tussen droom en daad geen wetten of praktische bezwaren in de weg staan, dan kan men in principe op ieder willekeurig moment een nieuwe provincie instellen, gemeenten samenvoegen, een stichting oprichten of een bv ontbinden. Dit alles kan bovendien relatief eenvoudig worden bewerkstelligd, namelijk door het verrichten van rechtshandelingen.

Een derde kenmerk van deze categorie rechtssubjecten - een kenmerk dat direct in het oog springt wanneer men de rechtspersonen vergelijkt met de natuurlijke personen - is de grote diversiteit aan rechtspersonen. Zo zijn er niet alleen staten en internationale organisaties, maar ook verenigingen, stichtingen, nv's, bv's, enzovoort. Het is daarnaast verder opmerkelijk dat de individuele exemplaren van een bepaald type nu juist weer volledig aan elkaar gelijk zijn. Bij de rechtspersonen is er dus zowel sprake van een grote mate van diversiteit tussen de genera, als van een strikte gelijkheid van de species van een bepaald genus.

Een vierde kenmerk van rechtspersonen is dat ze een grote mate van continuïteit vertonen. Deze continuïteit wordt dikwijls geprezen als één van de belangrijkste voordelen van rechtspersonen. Publiekrechtelijke rechtspersonen - zoals de Staat der Nederlanden of de Gemeente Amsterdam - kunnen in principe eeuwenlang blijven voortbestaan, zodat men met behulp van deze rechtspersonen het publieke leven op een duurzame wijze vorm kan geven. Privaatrechtelijke rechtspersonen - die volgens de wet worden opgericht voor onbepaalde tijd (art. 2:17 BW) - kunnen daarnaast worden ingezet om ook private ondernemingen en ideële organisaties van de nodige continuïteit te voorzien. Vanuit een diachronisch perspectief zou men deze opmerkelijke continuïteit van rechtspersonen wellicht nog iets preciezer kunnen typeren als 'continuïteit met behoud van identiteit'. Wanneer een rechtspersoon enkele eeuwen achter elkaar bestaat, dan is het 
immers bepaald niet uitgesloten dat de vermogensrechtelijke rechtspositie of de interne ambtenorganisatie van die rechtspersoon zo nu en dan radicale transformaties ondergaat. Desondanks gaan juristen er dan toch vanuit dat we nog steeds met precies dezelfde rechtspersoon te maken hebben.

Een vijfde kenmerk van rechtspersonen is dat ze - net als natuurlijke personen dragers van rechten, plichten en bevoegdheden zijn. Dit dragen van rechten, plichten en bevoegdheden is zelfs de essentie van de rechtssubjectiviteit van de rechtspersoon. Zoals ik hierboven heb betoogd, moet dit 'dragen' worden uitgelegd in termen van het persoonlijke element van de rechtsnorm. In bijvoorbeeld de norm 'Jan moet 500 euro aan betalen aan Piet', treedt de eigennaam 'Jan' op als het persoonlijke element van de norm, zodat we kunnen zeggen dat Jan de 'drager' is van de plicht om 500 euro te betalen aan Piet. Om een zelfstandige 'drager' van rechten, plichten en bevoegdheden te kunnen zijn, zal een rechtspersoon dus moeten kunnen verschijnen als het persoonlijke element van een geldige rechtsnorm. Bijvoorbeeld: 'Koninklijke Philips N.V moet 500 euro betalen aan Piet.'

Het laatste kenmerk van rechtspersonen hangt samen met het eerste. Omdat rechtspersonen onstoffelijk zijn, hebben zij ook geen lichaam. Rechtspersonen kunnen daarom niet zélf het wegdek onderhouden, documenten vervalsen of uitlatingen in de pers doen. Het gedrag van mensen van vlees en bloed kan echter wel aan rechtspersonen worden toegeschreven of toegerekend. In het burgerlijk recht wordt menselijk gedrag bijvoorbeeld toegerekend op basis van het maatschappelijk verkeerscriterium, in het strafrecht geschiedt dit op basis van het criterium van de redelijke toerekening. ${ }^{82} \mathrm{Bij}$ een dergelijke toerekening fungeert de rechtspersoon als een 'toerekeningspunt' van menselijk gedrag.

In het vervolg van deze paragraaf zal ik bezien in hoeverre de alternatieve theorieën van de rechtspersoon deze zes algemene kenmerken kunnen verklaren. Ik begin wederom met de theorieën die de rechtspersoon als een extra-systemische entiteit hebben gepresenteerd.

\section{(a) De rechtspersoon als extra-systemische entiteit}

Wanneer we nagaan in hoeverre de alternatieve theorieën van de rechtspersoon een adequate verklaring kunnen bieden voor de hierboven besproken kenmerken, dan blijkt al gauw dat de sociaal-biologische en sociologische theorieën op werkelijk alle punten jammerlijk falen. Zo is het kenmerk van de onstoffelijkheid al direct funest voor deze theorieën. Wanneer de rechtspersoon werkelijk een groep mensen in de empirische werkelijkheid zou zijn - die eventueel tezamen nog een nieuw organisme zouden vormen - dan wordt het immers volstrekt onduidelijk waarom deze mensen zich niet in een rechtszaal zouden kunnen vertonen of waarom deze mensen niet met $z$ 'n allen tegelijk in een gevangenis zouden kunnen worden opgesloten. Zeker bij bv's en stichtingen met kleine feitelijke organisaties zou dit toch tot de mogelijkheden moeten behoren. Ook het kenmerk van de crea- 
tie en ontbinding door rechtshandelingen stelt ons bij deze theorieën voor de nodige raadsels. Het creëren en ontbinden van een rechtspersoon kan bij deze theorieën immers niet veel anders betekenen dan het creëren en laten verdwijnen van een groep mensen. Wetgevers, rechters en notarissen zijn echter geen demiurgen, die naar believen hele groepen mensen de werkelijkheid in en uit kunnen toveren. Door het verrichten van rechtshandelingen kunnen zij uiteraard wel allerlei rechtspersonen creëren, maar geen mensen van vlees en bloed. Bij het creeren of ontbinden van een rechtspersoon verandert men dan ook enkel de inhoud van het rechtssysteem en niet ook de stand van zaken in de empirische werkelijkheid. Hetzelfde geldt uiteraard ook voor het wijdverbreide sociologisch-geografische staatsbegrip. Wanneer de rechtspersoon 'staat' werkelijk een stuk grond met daarop een bevolking en een effectieve regering zou zijn, dan zou het einde van een staat niets anders kunnen betekenen dan het plotselinge verdwijnen van een deel van de planeet, inclusief het aldaar vertoevende deel der mensheid. Hoewel tal van staten reeds lang niet meer bestaan, heeft een dergelijke catastrofe zich in de wereldgeschiedenis nog nooit voorgedaan. Sociologische theorieën kunnen evenmin een bevredigende verklaring geven voor de diversiteit tussen de genera en de gelijkheid van de species. Waarom is bijvoorbeeld de ene op winstmaximalisatie gerichte groep mensen een bv en de andere een nv? Hoe zouden we op een zuiver sociologische manier moeten vaststellen of Vaticaanstad een kerkgenootschap of een staat is? En hoe kunnen groepen die volstrekt tegengestelde doelen nastreven, toch identieke verenigingen zijn?

Dat het niet best afloopt met rechtstheorieën die de fundamentele begrippen van het recht in termen van de empirische werkelijkheid definiëren, is onder rechtstheoretici algemeen bekend, sinds Hart zijn beroemde kritiek op de rechtstheorie van Austin heeft geformuleerd. Austin had het recht beschreven als een set bevelen (commands) waaraan extra kracht wordt bijgezet door de dreiging van sancties (backed by the threat of sanctions). De verbindende kracht van deze bevelen verklaarde Austin door erop te wijzen dat zij waren uitgevaardigd door een als feitelijk persoon begrepen soeverein (sovereign), die in de regel door de bevolking wordt gehoorzaamd (habitually obeyed). ${ }^{83}$ Hoewel dit alles vanuit een synchronisch perspectief nog vrij plausibel klinkt, raakt een dergelijke op de empirische werkelijkheid georiënteerde theorie van het recht vanuit een diachronisch perspectief hopeloos in de problemen. Want hoe moeten we de continuiteit van het recht verklaren, wanneer de eerste soeverein wordt vervangen door een tweede, die nog nooit één bevel heeft uitgevaardigd en daarom ook nog nooit door de bevolking kan zijn gehoorzaamd? ${ }^{84}$ Wanneer de door Austin in de empirische werkelijkheid aangewezen fenomenen met het verstrijken van de tijd één voor één bezwijken, dan gaat uiteindelijk ook zijn op deze vergankelijke feiten gebaseerde theorie van het recht met deze oude wereld ten onder. Het door Hart zo krachtig onderstreepte verschil tussen de continuïteit van het recht en de disconti-

83 John Austin, The Province of Jurisprudence Determined (Londen: John Murray, 1832).

84 Zie over 'The Habit of Obedience and the Continuity of Law': H.L.A. (Herbert) Hart, The Concept of Law, 2nd ed. (with a new Postscript), (New York: Oxford University Press, [1961] 1994), 50 e.v. 
nuïteit van de specifieke feitelijke constellaties in de empirische werkelijkheid kan uiteraard ook in stelling worden gebracht tegen de theorieën die de rechtspersoon in termen van deze discontinue feiten hebben gedefinieerd. Zo was bijvoorbeeld de feitelijke organisatie van de Gemeente Rotterdam in het jaar 1900 volstrekt anders samengesteld dan in het jaar 2000. Wanneer we op twee momenten te maken hebben met twee volstrekt verschillende groepen mensen in de empirische werkelijkheid, dan is het onduidelijk hoe we volgens de sociologische theorieën op beide momenten toch met precies dezelfde rechtspersoon te maken kunnen hebben. De onvermijdelijke discontinuïteit van de als rechtspersoon omschreven groep mensen in de empirische werkelijkheid leidt er eveneens toe dat er bij deze theorieën op de lange termijn geen sprake kan zijn van een permanente en stabiele drager van rechten, plichten en bevoegdheden, noch van een permanent en stabiel toerekeningspunt van menselijk gedrag. De theorieën die de rechtspersoon als een zuiver extra-systemische entiteit hebben gepresenteerd, kunnen de toets der kritiek dus op geen enkel punt doorstaan. In wezen gaat het bij al deze theorieën om een categoriefout tussen het Sein en het Sollen: men probeert een sociologische theorie te formuleren voor een zuiver juridisch fenomeen.

\section{(b) De rechtspersoon als hybride entiteit}

Dan de hybride theorieën. Het cruciale verschil tussen de sociologisch-juridische leer en de door mij verdedigde nominalistische leer betreft uiteraard de status van de feitelijke organisatie van de rechtspersoon. Volgens de nominalistische leer gaat het bij deze feitelijke organisatie om mensen in de empirische werkelijkheid die een bepaalde relatie met de rechtspersoon hebben, volgens de sociologischjuridische leer vormen deze mensen echter een integraal onderdeel van de rechtspersoon. Volgens de nominalistische leer is de rechtspersoon een zuiver juridische entiteit, volgens de sociologisch-juridische leer is de rechtspersoon daarentegen een hybride entiteit. Het idee dat een rechtspersoon 'half feit' en 'half recht' is, is heden ten dage weliswaar wijdverbreid, maar leidt bij een nadere beschouwing niettemin tot tal van problemen en eigenaardigheden. Ik noem er enkele.

Tegen de sociologisch-juridische leer kunnen ten eerste grofweg dezelfde bezwaren worden aangevoerd als tegen de zuiver sociologische leer. Wanneer de rechtspersoon werkelijk 'half feit' en 'half recht' zou zijn, dan zou men ook volgens deze leer bij het creëren of ontbinden van een rechtspersoon een groep mensen moeten creëren of laten verdwijnen. Zoals gezegd, kan men zoiets dergelijks echter niet bewerkstelligen door het verrichten van rechtshandelingen. Het voortbestaan van een rechtspersoon is daarnaast ook niet afhankelijk van het voortbestaan van de mensen van vlees en bloed die tezamen de feitelijke organisatie van de rechtspersoon vormen. De feitelijke organisatie van een stichting kan bijvoorbeeld bestaan uit drie bestuursleden: een voorzitter, een secretaris en een penningmeester. Wanneer deze mensen allemaal tegelijkertijd omkomen bij een vliegtuigongeluk, dan betekent dat niet dat de stichting daarmee ook ophoudt te bestaan. Zo kan de stichting ook na het ongeluk nog debiteur, crediteur of de eigenaar van auto's en gebouwen zijn. 
Volgens de nominalistische leer zijn natuurlijke personen en rechtspersonen twee wezenlijk van elkaar te onderscheiden rechtssubjecten, die hooguit bepaalde juridische relaties met elkaar kunnen aangaan. Wanneer men een natuurlijk persoon daarentegen presenteert als een onderdeel van een rechtspersoon, dan kan men vervolgens de juridische relatie tussen die natuurlijke persoon en de rechtspersoon niet meer begrijpen. Zo is het bijvoorbeeld raadselachtig hoe we volgens de sociologisch-juridische leer de contractuele relatie tussen een bv en diens werknemer zouden moeten begrijpen. Wanneer de werknemer een integraal onderdeel van de bv zou vormen, dan zou de bv dus in feite 'intern' met zichzelf gecontracteerd moeten hebben: de 'juridische zijde' van de bv zou dan een contract moeten hebben gesloten met zijn eigen 'sociale zijde'. Het is evenmin duidelijk waarom het gedrag van bestuurders en werknemers, die als de 'sociale zijde' van de rechtspersoon reeds een integraal onderdeel van de rechtspersoon vormen, nog aan de 'juridische zijde' van de rechtspersoon zou moeten worden toegeschreven of toegerekend. De desbetreffende natuurlijke personen zijn volgens deze theorie immers zelf al rondwandelende stukjes rechtspersoon.

Wanneer men consequent de hand zou houden aan de sociologisch-juridische leer, dan zou bij een strafvervolging tegen een rechtspersoon in principe ook de gehele feitelijke organisatie van die rechtspersoon in de rechtszaal moeten verschijnen, niet als vertegenwoordigers van die rechtspersoon, maar als wezenlijke onderdelen daarvan. Om dit punt nog verder op scherp te stellen: wanneer men met Jellinek of Kooijmans zou aannemen dat de gehele bevolking een integraal onderdeel van de rechtspersoon 'staat' vormt, dan zal men ook moeten accepteren dat deze rechtspersoon talloze ziekten en psychische stoornissen heeft, dat de staat tegelijkertijd nuchter en dronken kan zijn, kan waken en kan slapen. Dergelijke gevolgtrekkingen worden door geen jurist geaccepteerd, maar zij laten wel duidelijk zien tot welke ongerijmdheden men uiteindelijk wordt gedwongen, wanneer men consequent zou willen volhouden dat een rechtspersoon (mede) bestaat uit een groep mensen.

De claim dat sommige rechtspersonen (mede) bestaan uit een stuk grond is overigens niet minder problematisch. Zo valt het ten eerste moeilijk in te zien hoe een stuk grond - tezamen met andere delen van de empirische werkelijkheid - rechten, plichten en bevoegdheden zou kunnen hebben en welk doel er met een dergelijke regeling gediend zou kunnen worden. Daarnaast moet er uiteraard een onderscheid worden gemaakt tussen geografie en rechtswetenschap. In geografische zin kan ik zeggen dat ik mij tegelijkertijd in Nijmegen, Gelderland en Nederland bevind, maar juridisch gezien is de grond in de Gemeente Nijmegen niet tegelijkertijd Nijmeegse, Gelderse en Nederlandse grond. Privaatrechtelijk gezien is slechts een gedeelte van die grond in eigendom bij de Gemeente Nijmegen. Het overige deel is in handen van andere publiekrechtelijke rechtspersonen, privaatrechtelijke rechtspersonen en natuurlijke personen. Publiekrechtelijk gezien gaat het daarnaast niet om de grond, maar om de ruimtelijke - en dat wil zeggen driedimensionale - afbakening van bevoegdheden. In het Nederlandse recht liggen de publiekrechtelijke bevoegdheden niet bij de publiekrechtelijke rechtspersonen, 
maar bij de bestuursorganen van die rechtspersonen. Publiekrechtelijk gezien kan ik dus niet zeggen dat ik mij bevind in de rechtspersoon 'Gemeente Nijmegen' of op de rechtspersoon 'Provincie Gelderland'. Ik bevind me veeleer binnen de overlappende bevoegdheidssferen van verschillende publiekrechtelijke bestuursorganen. Dat de bevoegdheden van die bestuursorganen in ruimtelijke zin zijn afgebakend, wil uiteraard niet zeggen dat die bestuursorganen zélf - of de rechtspersonen waartoe zij behoren - een extensie in de ruimte hebben. Rechtspersonen en hun organen zijn immers geen onderdeel van de empirische werkelijkheid, maar namen binnen het rechtssysteem.

In tegenstelling tot de tot nu toe bekritiseerde sociologisch georiënteerde theorieën van de rechtspersoon, lijkt de fictieleer het op het eerste gezicht bijzonder goed te doen. Wanneer deze leer op de juiste manier zou worden uitgewerkt, dan zou zij in principe alle kenmerken van de rechtspersoon moeten kunnen verklaren. De fictieleer is echter onverenigbaar met hetgeen daadwerkelijk is gegeven in het rechtssysteem en de rechtspraktijk. Wanneer deze leer waar zou zijn, dan zouden beide er volstrekt anders uit moeten zien. Een 'fictie' zou men ten eerste kunnen omschrijven als een voorstelling van zaken in ons bewustzijn, die in strijd is met de werkelijkheid en die wordt begeleid - of in ieder geval zou moeten worden begeleid - door het bewustzijn dat de inhoud van die voorstelling niet strookt met de werkelijkheid. ${ }^{85}$ Een 'fictief persoon' zou dan vervolgens kunnen worden omschreven als de voorstelling van een niet bestaand persoon van wie we weten - of in ieder geval zouden moeten weten - dat hij of zij niet bestaat.

In de praktijk van het recht kan het uiteraard niet gaan om louter subjectieve voorstellingen van fictieve personen. De rechtsgenoten moeten immers aan elkaar duidelijk kunnen maken om welke rechtspersoon het in een bepaalde zaak gaat en iedereen zal daarom precies dezelfde voorstelling van deze of gene fictieve persoon moeten hebben. Hoe kan men er nu voor zorgen dat miljoenen mensen steeds precies dezelfde fictieve personen voor ogen hebben? Het komt mij voor dat dit alleen maar mogelijk is, wanneer men afbeeldingen van die fictieve personen zou maken. Om de rechtsgenoten in staat te stellen om op een volstrekt ondubbelzinnige manier aan elkaar duidelijk te maken om welke rechtspersoon het in een bepaalde zaak gaat, zal er dus van overheidswege voor iedere afzonderlijke rechtspersoon - en er zijn er alleen al in het Nederlandse rechtssysteem enkele honderdduizenden - een volstrekt unieke afbeelding van een fictief persoon moeten worden ontworpen. De gehele galerij van fictieve personen zal daarbij in grote hoeveelheden in omloop moeten worden gebracht, zodat iedereen snel kan opzoeken om welke rechtspersoon het gaat, wanneer hem of haar een afbeelding van een fictief persoon wordt getoond. Ook voor de inhoud van het rechtssysteem zou de fictieleer uiteraard belangrijke gevolgen hebben. Binnen het rechtssysteem treden rechtspersonen op als het persoonlijke element van bepaalde rechtsnormen, zodat de van overheidswege geproduceerde afbeeldingen

85 Cf. Hans Vaihinger, Die Philosophie des Als Ob. System der theoretischen, praktischen und religiösen Fiktionen der Menschheit auf Grund eines idealistischen Positivismus (Leipzig: Felix Meiner, 1922), 127. 
van fictieve personen ook nauwkeurig zullen moeten worden gereproduceerd in de bepalingen van bijvoorbeeld verdragen, wetten of contracten. Uiteindelijk zou het hele rechtssysteem dus moeten wemelen van de plaatjes van fictieve personen.

Dit is uiteraard niet hoe het er in het rechtssysteem en de rechtspraktijk aan toegaat. Een advocaat die aan een rechter duidelijk wil maken namens welke rechtspersoon hij optreedt, laat geen afbeelding van een fictief persoon zien, maar noemt een naam, bijvoorbeeld: 'Hartstichting' of 'Nierstichting'. Ook in verdragen en contracten treffen we bij de handtekeningen geen plaatjes van fictieve personen aan, maar namen. De inhoud van het rechtssysteem bevat dus wel een heleboel namen, maar geen afbeeldingen van fictieve personen. Wellicht zou men de fictieleer in tweede instantie nog zo kunnen uitleggen dat rechtspersonen namen zijn die verwijzen naar fictieve personen. Uit het hierboven besproken overzicht van de alternatieve theorieën van de rechtspersoon blijkt echter al direct dat zeker niet iedereen bij de namen die we rechtspersonen noemen aan fictieve personen denkt, laat staan dat iedereen aan precies dezelfde fictieve personen denkt bij namen zoals 'Gemeente Littenseradiel' of 'Stichting tot Steun Openbaar Kleuteronderwijs Ittersum'. In beide gevallen spoort de fictieleer dus niet met hetgeen daadwerkelijk is gegeven in het rechtssysteem en de rechtspraktijk en welbeschouwd is de fictieleer daarmee dus zélf een fictie.

\section{(c) De rechtspersoon als intra-systemische entiteit}

Ten slotte de op het rechtssysteem georiënteerde theorieën die de rechtspersoon hebben geduid als een (gepersonifieerd) complex van normen. Ook deze theorieën slagen er niet in om de kernmerken van de rechtspersoon op een bevredigende manier te verklaren. Zij bieden ten eerste geen adequate verklaring voor het bestaan van verschillende typen rechtspersonen, noch voor de gelijkheid die kenmerkend is voor de individuele exemplaren van zo'n type. Hoe zouden we bijvoorbeeld moeten vaststellen of een bepaalde groep ambten een gemeente of een provincie is? En hoe kunnen we weten of een bepaald vermogen een nv of een bv is? Omdat de inhoud van een als rechtspersoon gepresenteerd complex van normen aan een voortdurende verandering onderhevig kan zijn, hebben ook deze theorieën problemen met het kenmerk van de continuïteit met behoud van identiteit. Zo kan een privaatrechtelijk vermogen dat als een rechtspersoon wordt gepresenteerd aan het begin van de eeuw uit geheel andere vermogensbestanddelen zijn opgebouwd dan aan het eind van de eeuw, zonder dat juristen ervan uitgaan dat we om die reden te maken hebben met een nieuwe rechtspersoon. In het volkenrecht is het verder algemeen erkend dat een radicale transformatie van de interne ambtenorganisatie - zoals bijvoorbeeld ten tijde van de Russische revolutie - geen enkele invloed heeft op de continuïteit en de identiteit van de staat als volkenrechtelijk rechtssubject.

De theorieën die de rechtspersoon als een complex van normen hebben gepresenteerd kunnen evenmin uitleggen hoe een rechtspersoon de drager van rechten, plichten en bevoegdheden kan zijn, aangezien de drager bij deze theorieën volle- 
dig in het niet verdwijnt. Wanneer men bijvoorbeeld de rechtspersoon 'Koninklijke Philips N.V.' begrijpt als een vermogen - dat wil zeggen als een geheel van vermogensrechtelijke rechten en plichten - dan eindigt men uiteindelijk met een vermogen dat een vermogen draagt. Hetzelfde geldt voor de duiding die Kelsen en Logemann aan het begrip 'ambt' hebben gegeven: daar eindigt men uiteindelijk met publiekrechtelijke bevoegdheden die publiekrechtelijke bevoegdheden dragen. Nog afgezien van het feit dat het eigenaardig zou zijn om aan een complex van rechtsnormen een juridisch vastgelegde naam toe te kennen, zouden rechtsnormen die op rechtspersonen van toepassing zijn volgens deze theorieën dus conglomeraten van andere rechtsnormen moeten normeren, hetgeen nogal onzinnig lijkt.

Ten slotte kunnen ook deze theorieën niet verklaren hoe rechtspersonen zelfstandige toerekeningspunten kunnen zijn. Zo zijn bijvoorbeeld zelfstandige bestuursorganen (zbo's) publiekrechtelijk gezien onderdelen van de centrale overheid, terwijl zij privaatrechtelijk gezien dikwijls zelfstandige rechtspersonen zijn. Wanneer de rechtspersoon 'staat' de ambtenorganisatie van de centrale overheid zou zijn of de abstractie of personificatie daarvan - dan zou die ene rechtspersoon 'staat' dus tegelijkertijd allerlei privaatrechtelijke rechtspersonen 'in' zich moeten dragen. Het is onduidelijk hoe zbo's dan nog zelfstandige dragers van een privaatrechtelijk vermogen zouden kunnen zijn of hoe men een handeling aan hen zou kunnen toeschrijven, zonder deze tegelijkertijd ook aan de rechtspersoon 'staat' toe te schrijven. Dit probleem van 'diffuse toerekening' of 'doorrekening' speelt het sterkst bij Kelsens opvatting van de staat. Het nationale rechtssysteem - dat door hem wordt gepresenteerd als de rechtspersoon 'staat' - omvat immers vrijwel alle normatieve subsystemen, die volgens zijn leer weer de basis vormen voor de constructie van de overige rechtssubjecten. Wanneer men Kelsens theorie zou accepteren, dan zou men dus niets aan een rechtspersoon of een natuurlijk persoon kunnen toeschrijven, zonder dit tegelijkertijd ook aan de staat toe te schrijven. Net als bij de sociologisch georiënteerde theorieën, kan de rechtspersoon dus ook bij deze theorieën niet fungeren als een permanente en stabiele drager van rechten, plichten en bevoegdheden, noch als een uniek en zelfstandig toerekeningspunt.

\section{Conclusie}

De conclusie van deze studie moet luiden dat geen van de tot nu toe gepresenteerde theorieën van de rechtspersoon de toets der kritiek kan doorstaan. Met uitzondering van de fictieleer, hebben al deze theorieën weliswaar gewezen op zaken die in een bepaalde relatie tot de rechtspersoon staan - zoals de feitelijke organisatie, de organen of het vermogen van de rechtspersoon - maar geen van deze theorieën heeft de rechtspersoon zélf weten te treffen. Aangezien mijn nominalistische leer wel in staat is om alle hierboven genoemde kenmerken van de rechtspersoon op een bevredigende manier te verklaren, houd ik haar voor de juiste. 